
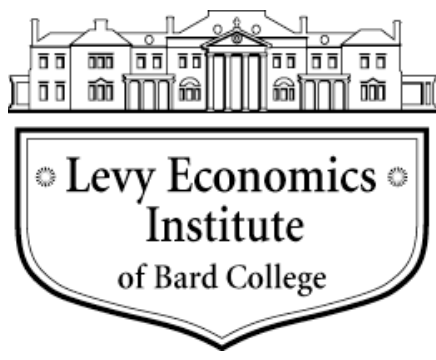

Working Paper No. 863

\title{
The Empirics of Long-Term US Interest Rates
}

\author{
by \\ Tanweer Akram \\ Thrivent Financial \\ Huiqing Li \\ Central University of Finance and Economics
}

March 2016

\begin{abstract}
Tanweer Akram is director of global public policy and economics at Thrivent Financial. Huiqing Li is assistant professor in the School of National Fiscal Development at the Central University of Finance and Economics. The authors thank the participants of various seminars for their valuable suggestions. Disclaimer: The authors' institutional affiliations are provided solely for identification purposes. Views expressed are solely those of the authors and the standard disclaimer applies. The views are not necessarily those of Thrivent Financial, Thrivent Investment Management, or any affiliates. This is for information purposes only and should not be construed as an offer to buy or sell any investment product or service. Disclosure: Tanweer Akram's employer, Thrivent Financial, invests in a wide range of securities, including U.S. Treasury securities. Asset management services are provided by Thrivent Asset Management, LLC, a wholly owned subsidiary of Thrivent Financial for Lutherans.
\end{abstract}

Corresponding author: Tanweer Akram, Thrivent Financial, 625 Fourth Avenue South, Minneapolis, MN 55415-1665, USA; phone: 1612-844-4639; e-mail: tanweer.akram@thrivent.com. Huiqing Li, Academic Hall South, Room 404, Central University of Finance and Economics, 39 South College Road, Haidian District, Beijing 100081, China; phone: 86-10-6228 8272; fax: 86-10-6228 8605; e-mail: huiqing.li@cufe.edu.cn.

The Levy Economics Institute Working Paper Collection presents research in progress by Levy Institute scholars and conference participants. The purpose of the series is to disseminate ideas to and elicit comments from academics and professionals.

Levy Economics Institute of Bard College, founded in 1986, is a nonprofit, nonpartisan, independently funded research organization devoted to public service. Through scholarship and economic research it generates viable, effective public policy responses to important economic problems that profoundly affect the quality of life in the United States and abroad.

Levy Economics Institute

P.O. Box 5000

Annandale-on-Hudson, NY 12504-5000

http://www.levyinstitute.org

Copyright (C) Levy Economics Institute 2016 All rights reserved

ISSN 1547-366X 


\begin{abstract}
US government indebtedness and fiscal deficits increased notably following the global financial crisis. Yet long-term interest rates and US Treasury yields have remained remarkably low. Why have long-term interest rates stayed low despite the elevated government indebtedness? What are the drivers of long-term interest rates in the United States? John Maynard Keynes holds that the central bank's actions are the main determinants of long-term interest rates. A simple model is presented where the central bank's actions are the key drivers of long-term interest rates through short-term interest rates and various monetary policy measures. The empirical findings reveal that short-term interest rates, after controlling for other crucial variables such as the rate of inflation, the rate of economic activity, fiscal deficits, government debts, and so forth, are the most important determinants of long-term interest rates in the United States. Public finance variables, such as government fiscal balances or government indebtedness, as a share of nominal GDP appear not to have any discernable effect on long-term interest rates.
\end{abstract}

Keywords: Government Bond Yields; Long-Term Interest Rates; Short-Term Interest Rates; Monetary Policy

JEL Classifications: E43, E50, E60, G12 


\section{SECTION I: INTRODUCTION}

US government indebtedness and fiscal deficits increased notably following the global financial crisis. Yet long-term interest rates and US Treasury yields have remained remarkably low. Why have long-term interest rates stayed low despite higher government indebtedness and large fiscal deficits? What are the drivers of long-term interest rates in the United States? These are important research and policy questions. This paper examines these questions, both theoretically and empirically, drawing on a Keynesian framework.

John Maynard Keynes (1930) holds that the central bank's actions are the main drivers of longterm interest rates. He argues that the central bank's policy rate sets the short-term interest rate, which decisively influences the long-term interest rate. Moreover, he believes that short-term realizations induce the investor's long-term expectations as the investor develops his long-term outlook primarily based on extrapolating from the present and the past. The investor's view of the future is based on current conditions rather than proper mathematical expectations because probabilities cannot be meaningfully assigned to unknown events that may occur in an ontologically uncertain future. Keynes maintains that the investor is thus forced to take his cue about the long-term outlook from current conditions. In such a world, Keynes argues that the short-term interest rate and the changes in the short-term interest rate are the most important drivers of the long-term interest rate and the changes in the long-term interest rate. Following Keynes, a model of long-term interest rates and changes in long-term interest rates is constructed. Next, empirical evidence is provided here to show that the key drivers of long-term interest rates are short-term interest rates that the central bank largely controls. The short-term interest rate, after controlling for changes in other crucial variables (such as the rate of inflation, the rate of economic activity, and so forth), is the main driver in setting the long-term interest rate, rather than the government fiscal balance or the government indebtedness ratio.

Section II describes some important stylized facts about the evolution of both short-term interest rates and long-term interest rates in the US, various measures of inflation, industrial production and economic activity, business cycles, and government finance. Section III describes Keynes's views on the key drivers of the long-term interest rate in an ontologically uncertain world. 
Section IV presents a simple model of long-term interest rates and changes in long-term interest rates based on an interpretation of these views. Section V describes the data. Section VI describes the empirical approach undertaken here, reports the findings of numerous models that are calibrated to analyze the key drivers of long-term interest rates in the US, and interprets these findings from a vantage point of a Keynesian framework. Section VII concludes.

\section{SECTION II: THE STYLIZED FACTS}

A careful look at the evolution of interest rates, inflation, economic activity, and government finance variables provides valuable insights. It can also give useful pointers about the drivers of long-term interest rates and the underlying relationships between the key variables. The shaded areas in the figures below are recessions, as designated by the National Bureau of Economic Research (NBER).

Figure 1 shows the evolution of long-term interest rates in the US, as measured by the nominal

yields of US Treasury securities of selected tenors. Long-term interest rates generally rose from the early 1960s to early 1980s. Several features of the evolution of long-term interest rates become quite apparent from this figure. First, long-term interest rates rose sharply from the early 1960 s to the early 1980s but then have been on a declining trend from the early 1980s to the present. Second, interest rates generally tend to decline during or after a recession. Third, during the expansion phase of the business cycle, long-term interest rates vary but appear to usually rise before a recession. 
Figure 1: The Evolution of Long-Term Interest Rates

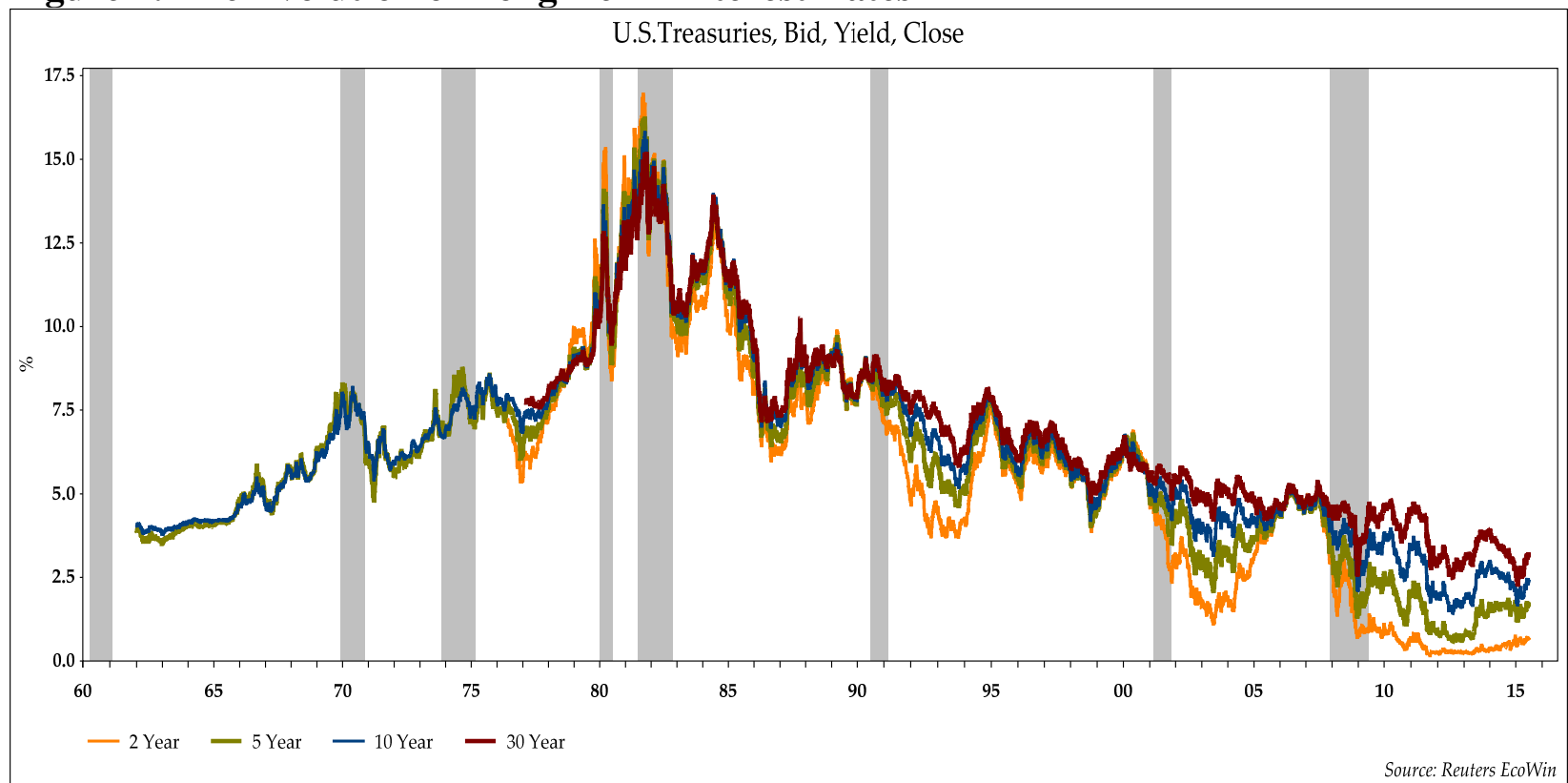

Figure 2 depicts the evolution of short-term interest rates, as measured by the nominal yields of US Treasury bills of 3-month and 6-month tenors. It also displays a similar pattern to that of the long-term interest rates. First, short-term interest rates generally rose from the early 1960s to early 1980s but then have been on a declining trend from the early 1980s to the present. Second, short-term interest rates decline during recessions as the Fed becomes accommodative and usually lowers its policy rate(s) in response to increased slack in the US economy. Third, shortterm interest rates tend to sometimes rise before the onset of a recession in response to the Fed's restrictive monetary policy and higher policy rate. Indeed, it is well-known that a negatively sloped yield curve, measured by the difference in the nominal yields between a 10-year Treasury note and 3-month Treasury bill, is one of the most reliable and consistently correct forward indicators of the onset of a recession in the US. 
Figure 2: The Evolution of Short-Term Interest Rates

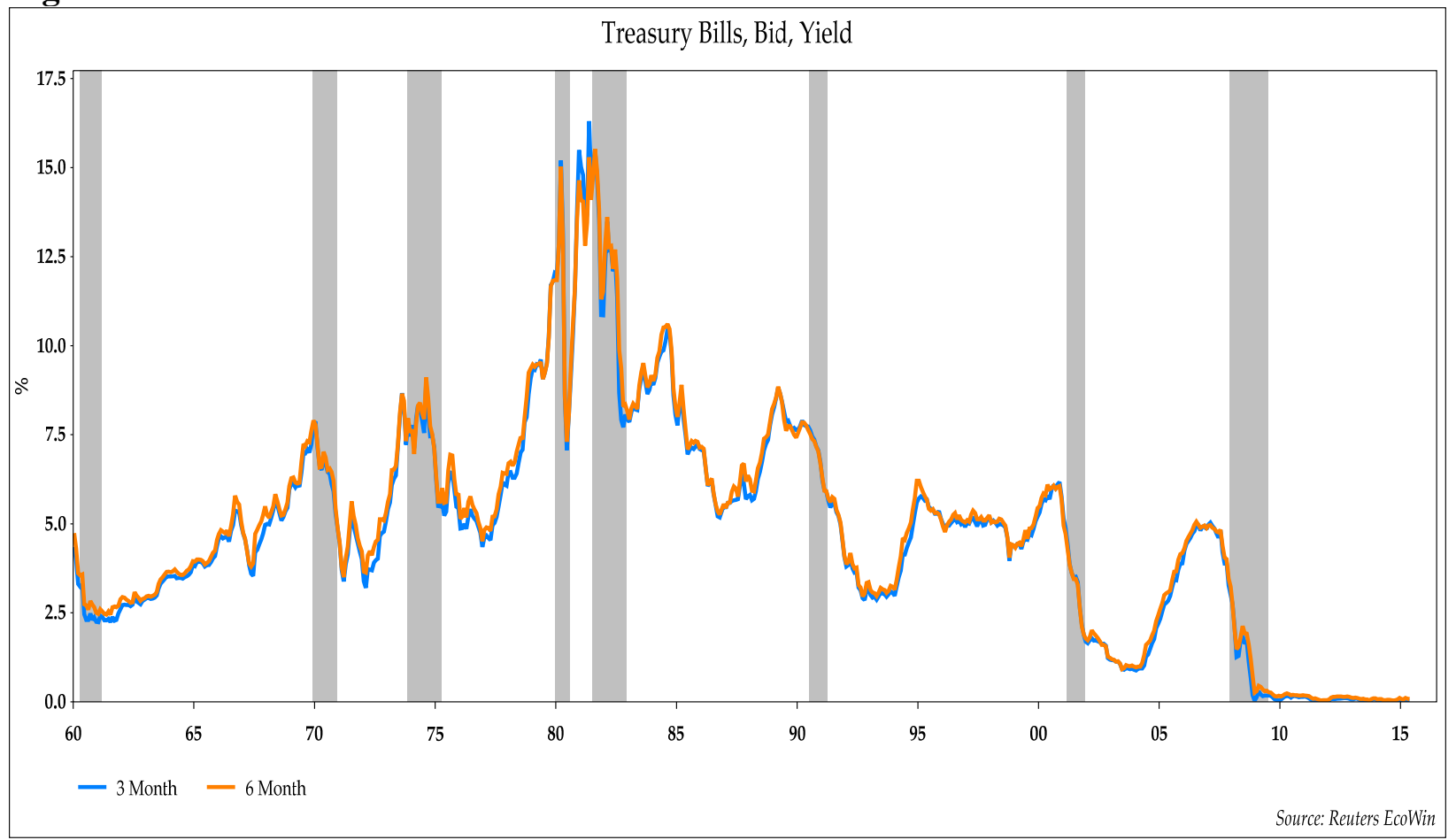

Figure 3 shows the evolution of total personal consumption expenditure (PCE) inflation and core personal consumption expenditure (core PCE) inflation. It reveals certain patterns in these measures of inflation. First, total PCE inflation tends to be more volatile than core PCE inflation. Second, both total and core PCE inflation rose in the 1970s and sharply so from the mid-1970s. Third, inflation began to decline after the two recessions in the 1980s and finally began to moderate after the recession in the early 1990s. 
Figure 3: The Evolution of PCE Inflation

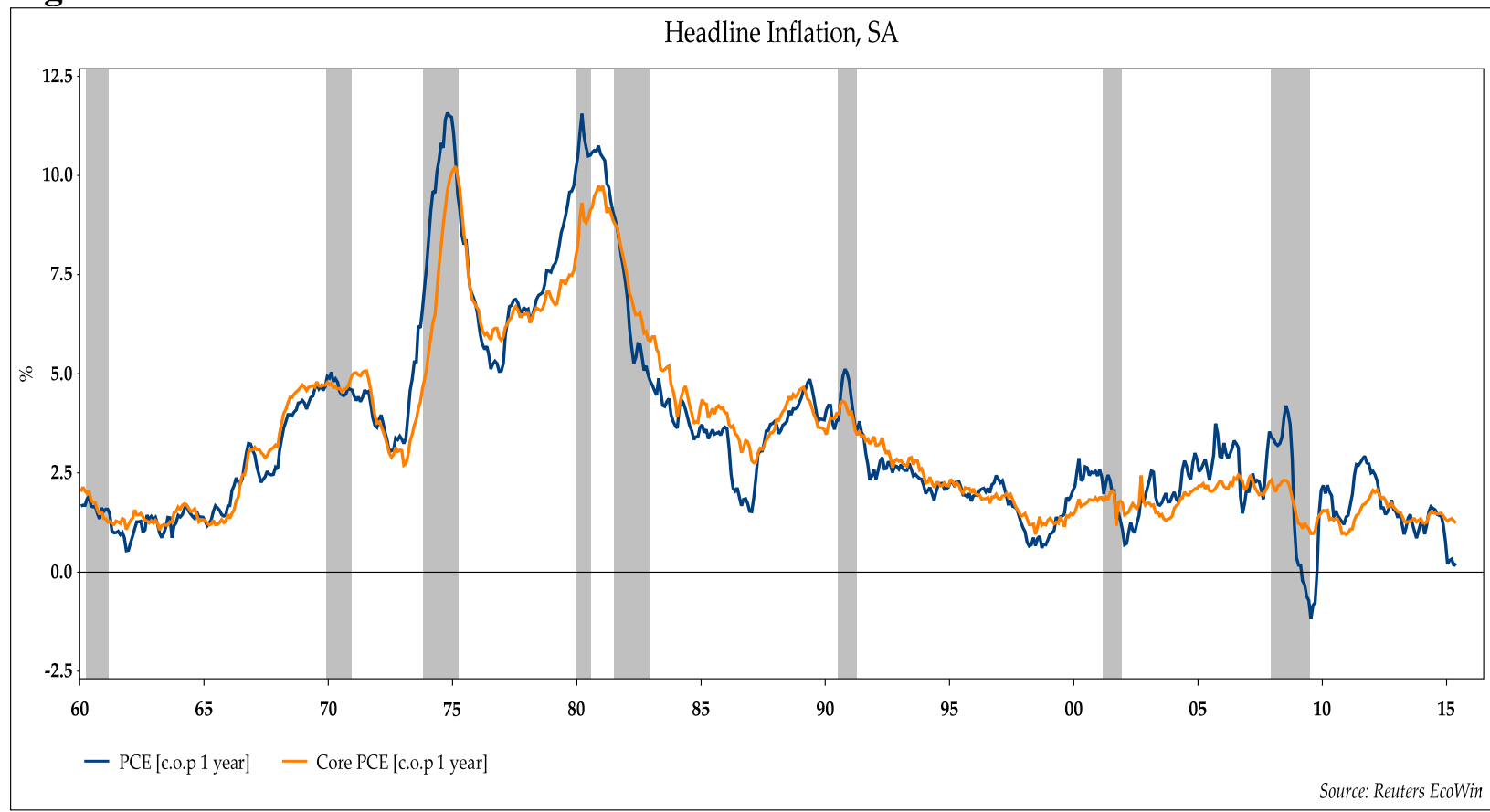

Figure 4 exhibits the evolution of total consumer price index (CPI) inflation and core consumer price index (core CPI) inflation. Total CPI and core CPI measures of inflation tend to be respectively higher than total PCE and core PCE measures of inflation. However, CPI measures of inflation also exhibit the same patterns as that of PCE measures of inflation.

Figure 4: The Evolution of CPI Inflation

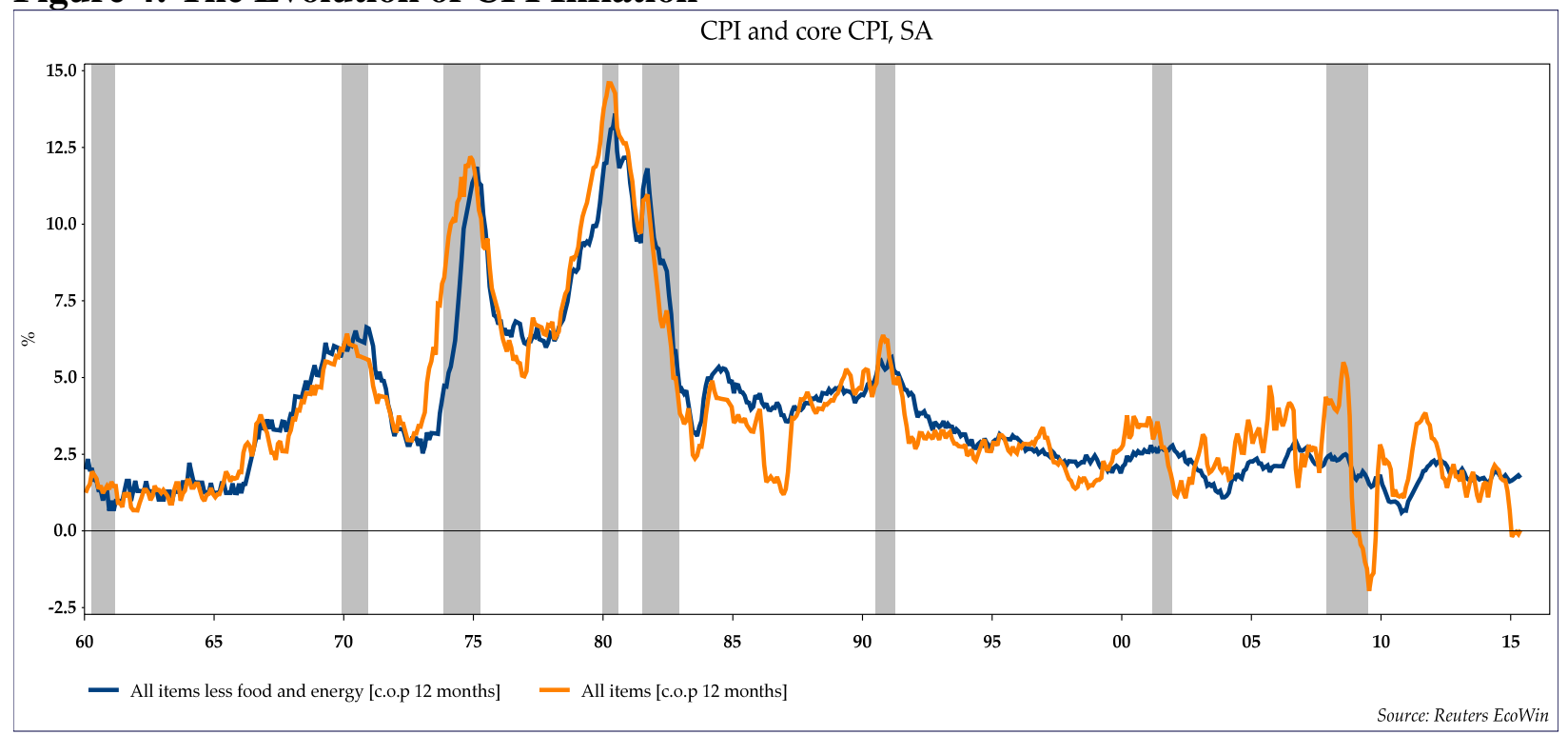


Figure 5 shows the evolution of the growth of industrial production (IPYOY), as measured by the year-over-year percentage change. Industrial production in the US economy generally tends to grow, except oftentimes before recessions and during recessions. Marked decreases in the growth of industrial production and its declines are very useful indicators of the likelihood of a recession and its onset.

Figure 5: The Evolution of Industrial Production

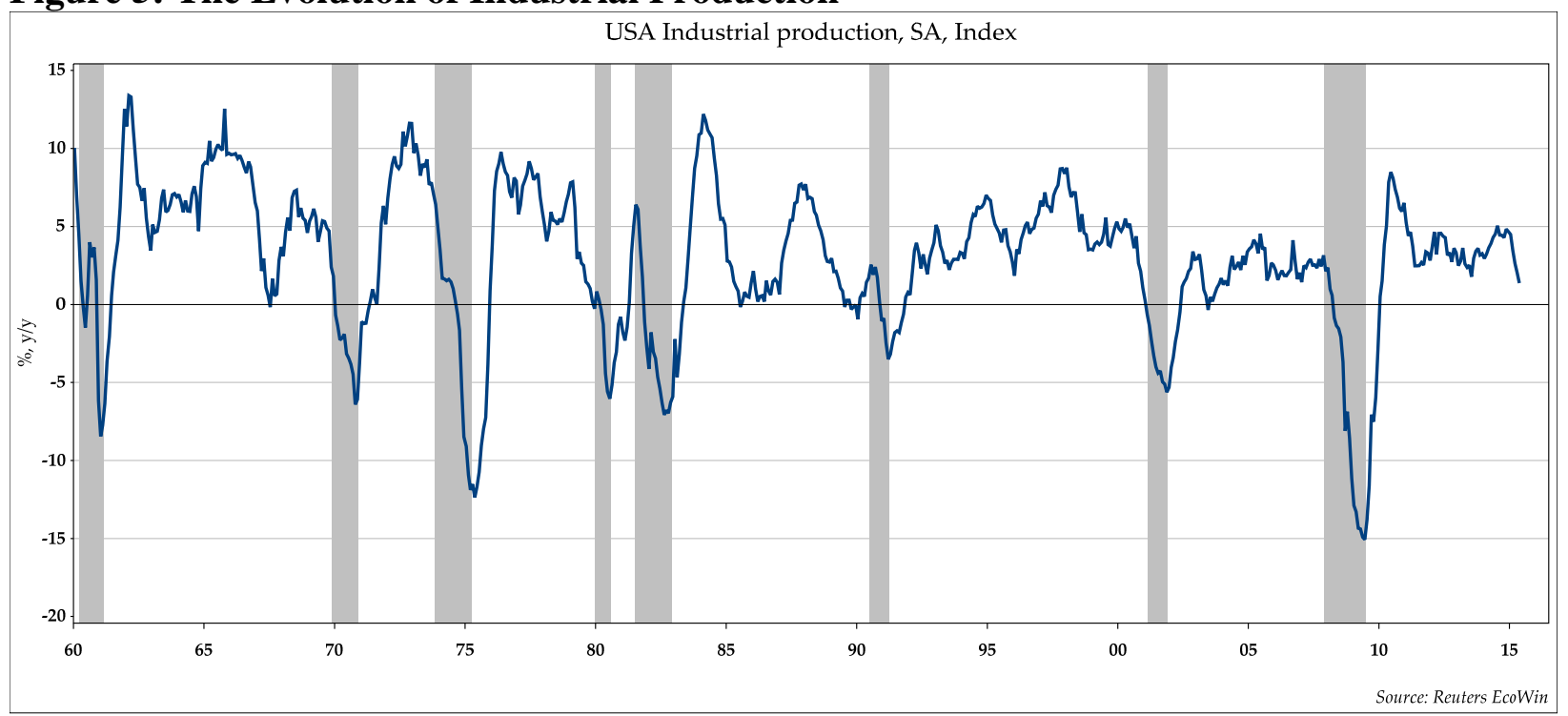

Figure 6 reveals the strong correlation between the growth of IPYOY and the growth of real gross domestic production in the US economy. It demonstrates that the growth of industrial production captures the vicissitudes of cyclical business conditions in the US quite well. 
Figure 6: The Pace of Industrial Production is Strongly Correlated with Real GDP Growth

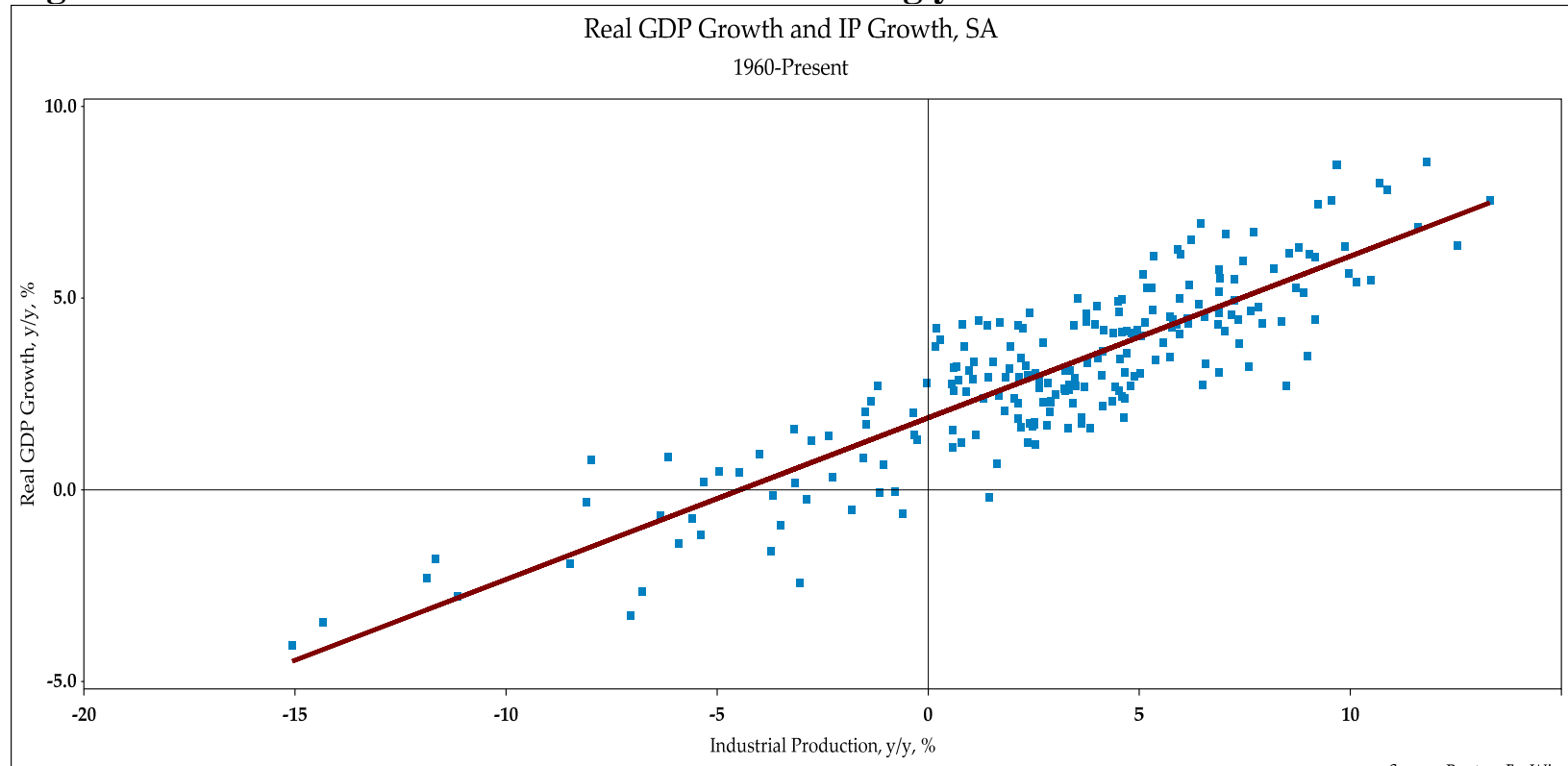

Source: Reuters EcoWin

Figure 7 displays the evolution of fiscal balance as a share of nominal GDP. Usually the US economy operates with a fiscal deficit. From the mid-1970s until the mid-1990s, the US usually incurred fiscal deficits of more than 3\% of nominal GDP per year, but in the mid-1990s fiscal deficits began to decline and the US economy experienced fiscal surpluses until the bust of the tech bubble and the recession of 2000. Following the recession at the turn of the century, the US got back to its pattern of fiscal deficits, which gradually narrowed with the onset of the housing bubble. However, as the housing bubble ended amid the global financial crisis, the US incurred large fiscal deficits in the ensuing years, although over the past couple of years the fiscal deficit has narrowed with the moderate recovery of the US economy. 


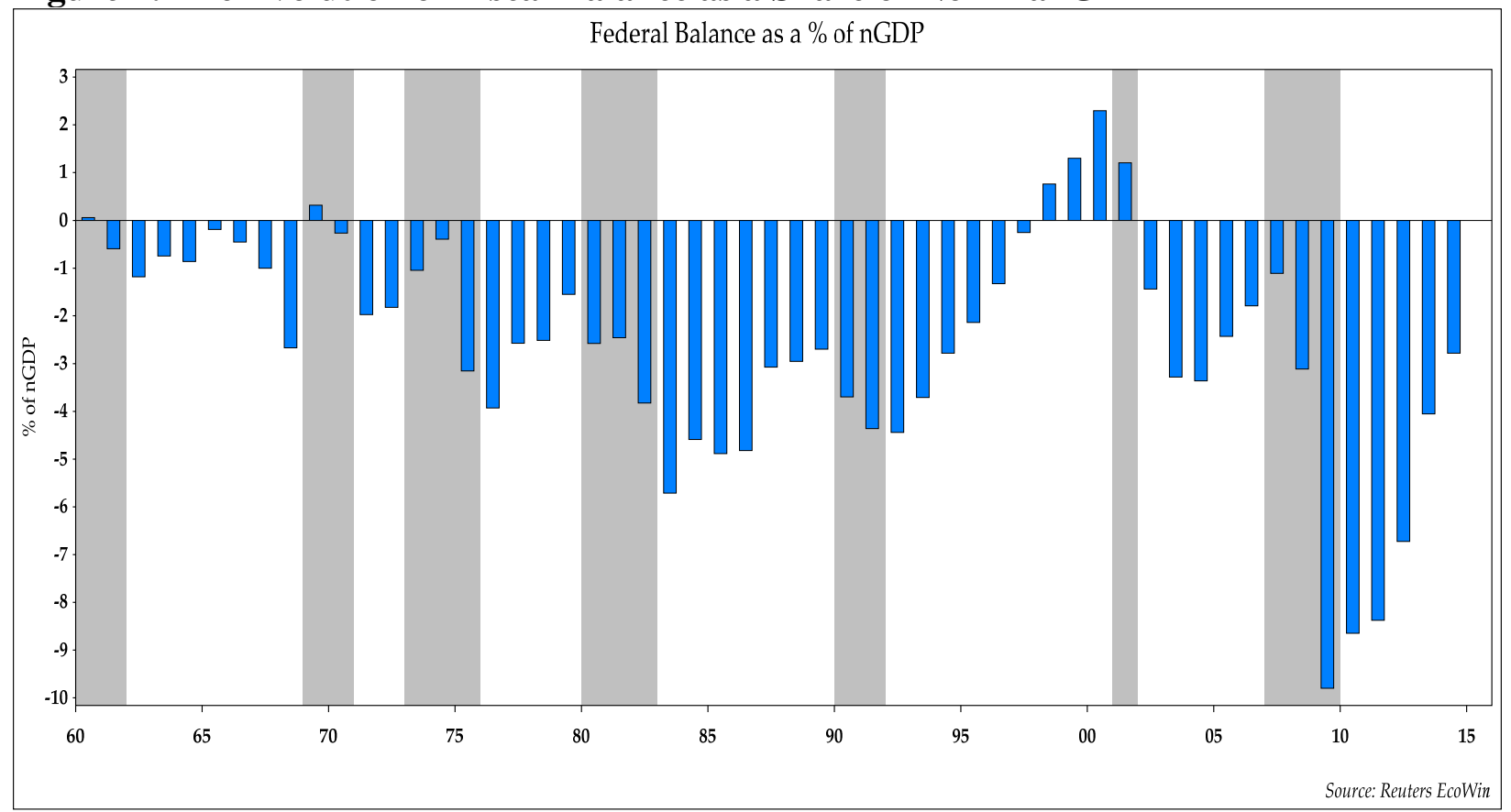

Figure 8 shows the evolution of total public debt as a share of nominal GDP. The US public debt stood in the range of $30 \%$ to $40 \%$ of nominal GDP from the mid-1960s to mid-1980s. It began to gradually creep higher from this range to around $60 \%$ of nominal GDP. It stayed in the range of around $60 \%$ of nominal GDP until 2008. After the global financial crisis and the Great Recession, public indebtedness rose sharply to over $90 \%$ of nominal GDP. It remains at these levels as of late 2014 . 


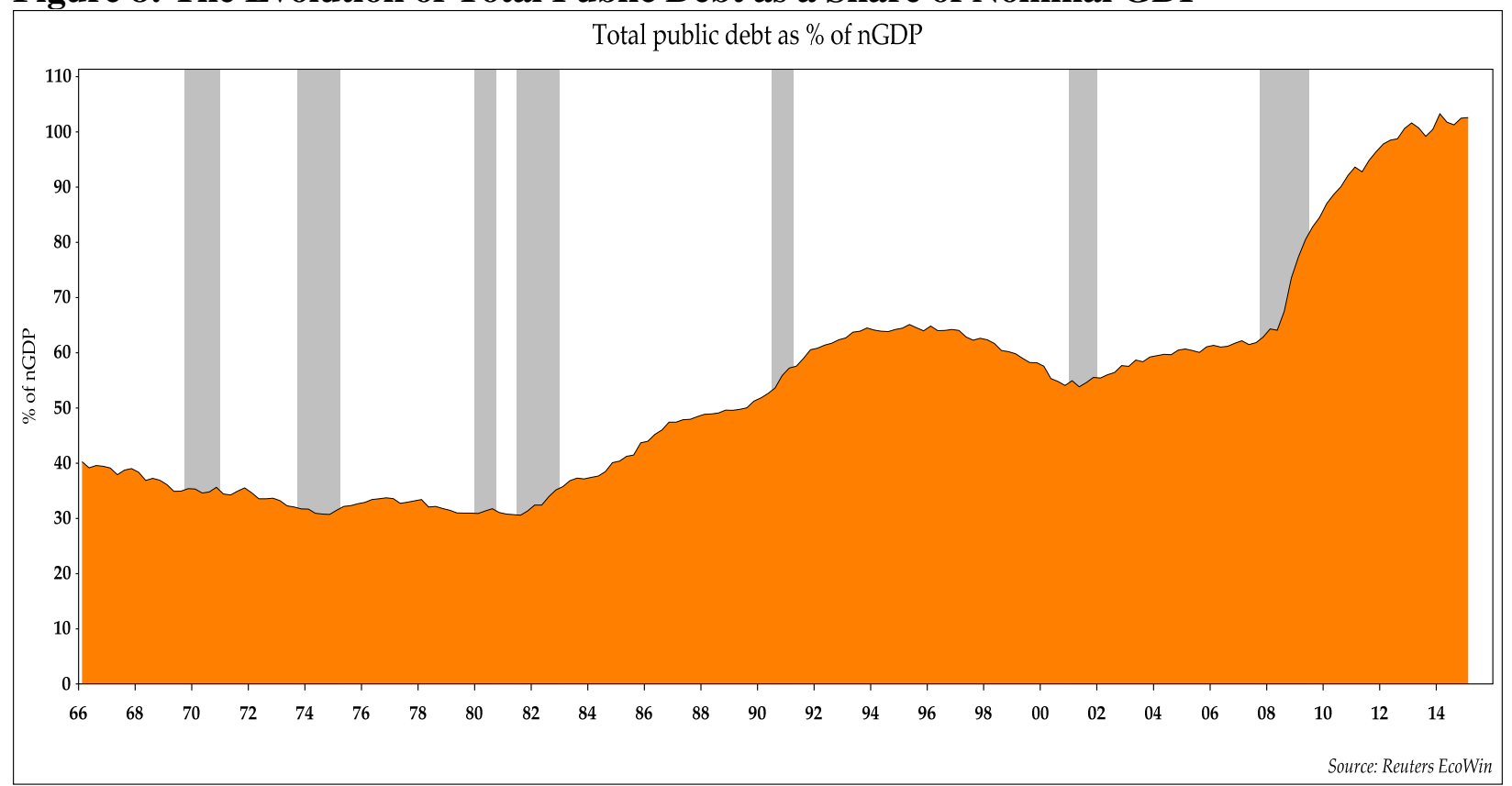

There is a very strong correlation between the long-term interest rate and the short-term interest rate. There is also fairly strong correlation between the percentage point changes, year over year, of the long-term interest rates and the percentage point changes of the short-term interest rates during the same period. Several figures below reveal these correlations.

Figure 9a is a scatterplot of the yields of US Treasury securities of a 2-year tenor and 3-month US Treasury bills. Figure $9 \mathrm{~b}$ is a scatterplot of the percentage point changes, year over year, in the yields of US Treasury securities of a 2-year tenor and 3-month US Treasury bills. 
Figure 9a: Scatterplot of the Yields of 2-year US Treasury Securities and 3-month US Treasury Bills

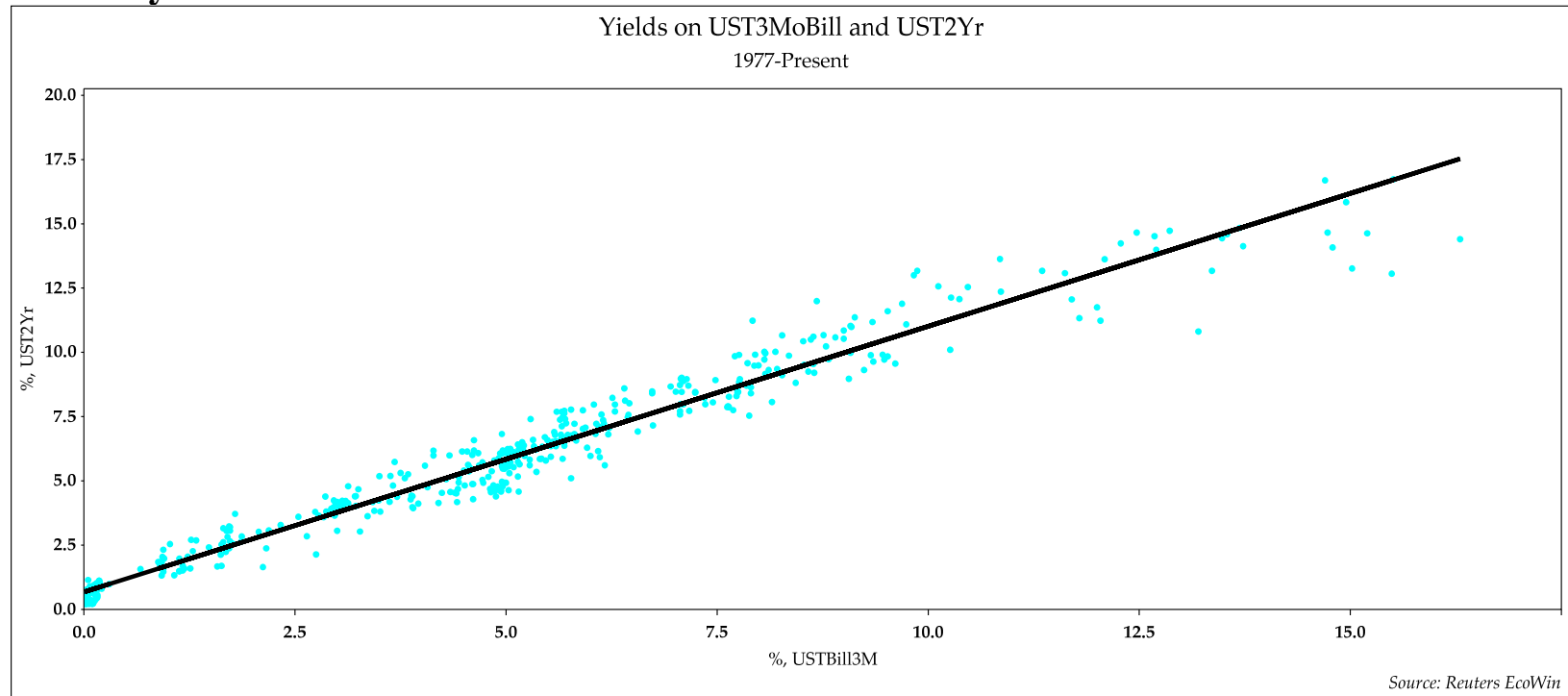

Figure 9b: Scatterplot of the Percentage Point Changes, Year over Year, in Yields of 2-year US Treasury Securities and 3-month US Treasury Bills

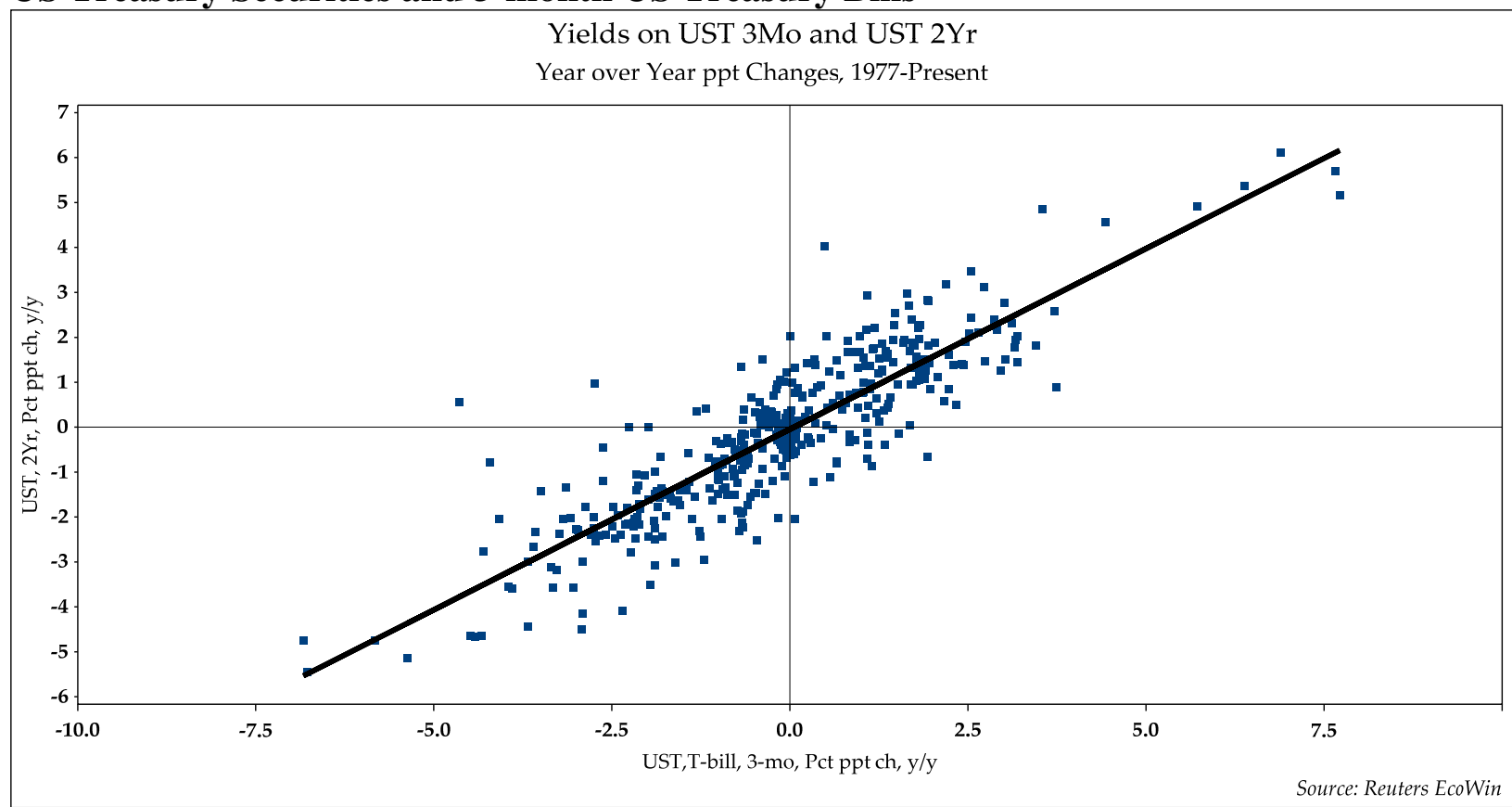

Figure 10a is a scatterplot of the yields of US Treasury securities of a 5-year tenor and 3-month US Treasury bills. Figure 10b is a scatterplot of the percentage point changes, year over year, in the yields of US Treasury securities of a 5-year tenor and 3-month US Treasury bills. 
Figure 10a: Scatterplot of the Yields of 5-year US Treasury Securities and 3-month US Treasury Bills

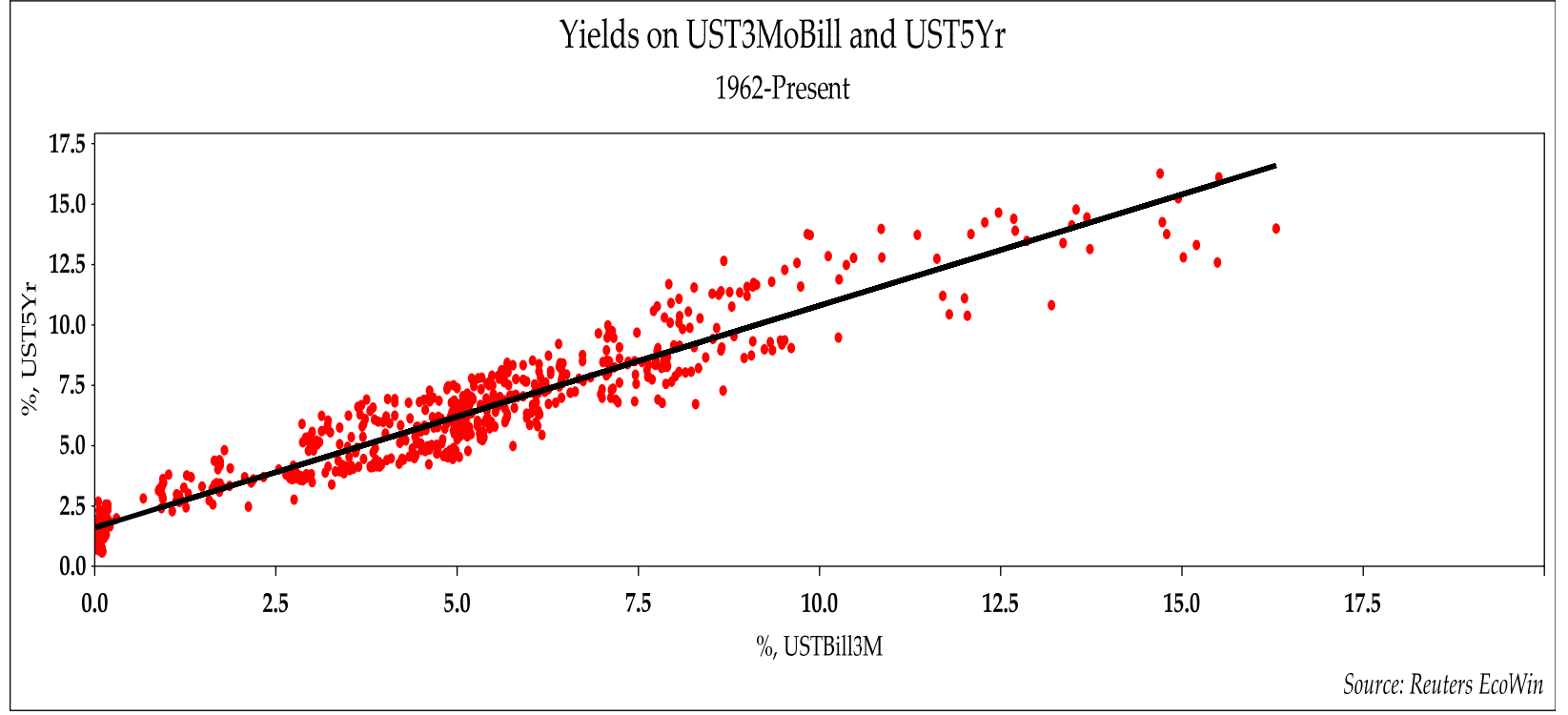

Figure 10b: Scatterplot of the Percentage Point Changes, Year over Year, in Yields of 5year US Treasury Securities and 3-month US Treasury Bills

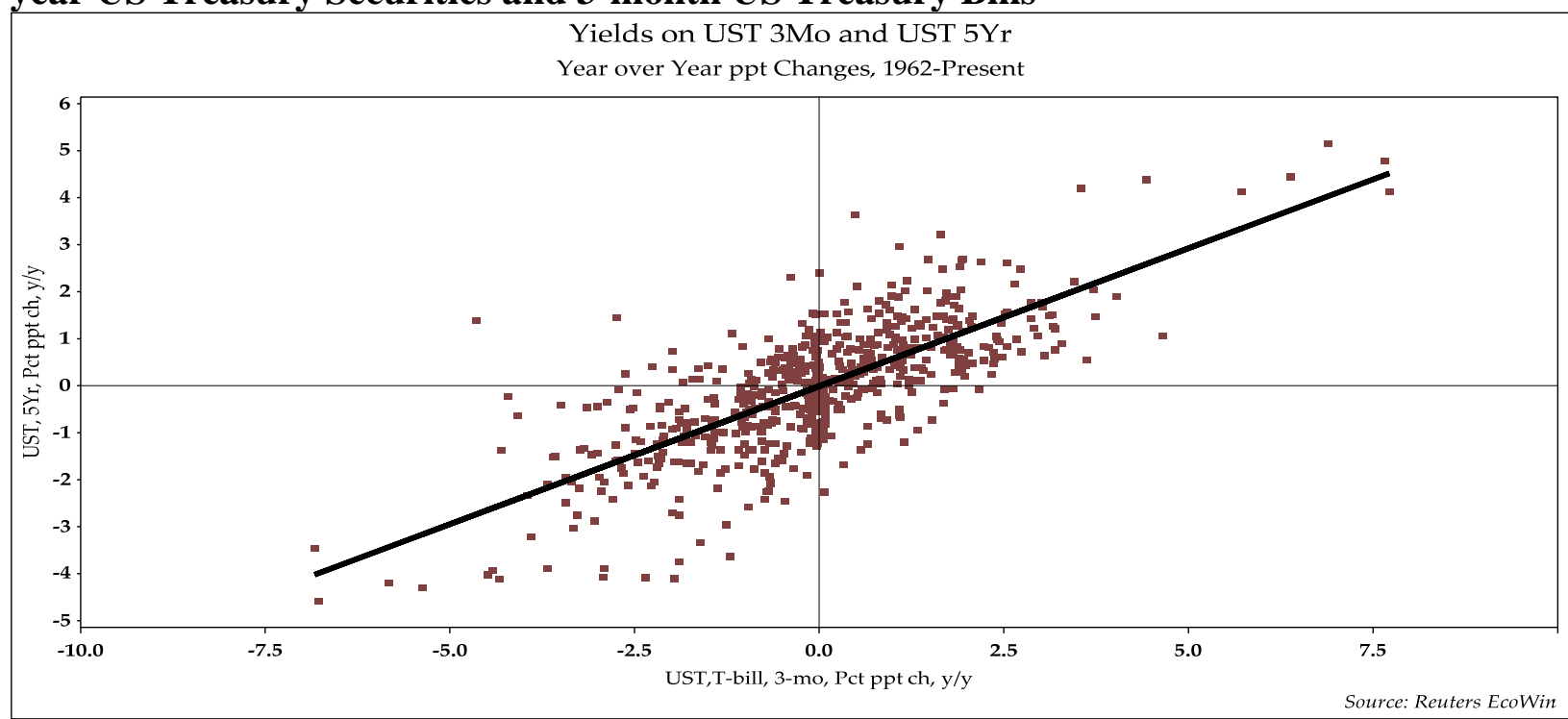

Figure 11a is a scatterplot of the yields of US Treasury securities of a 10-year tenor and 3-month US Treasury bills. Figure $11 \mathrm{~b}$ is a scatterplot of the percentage point changes, year over year, in the yields of US Treasury securities of a 10-year tenor and 3-month US Treasury bills. 
Figure 11a: Scatterplot of the Yields of 10-year US Treasury Securities and 3-month US Treasury Bills

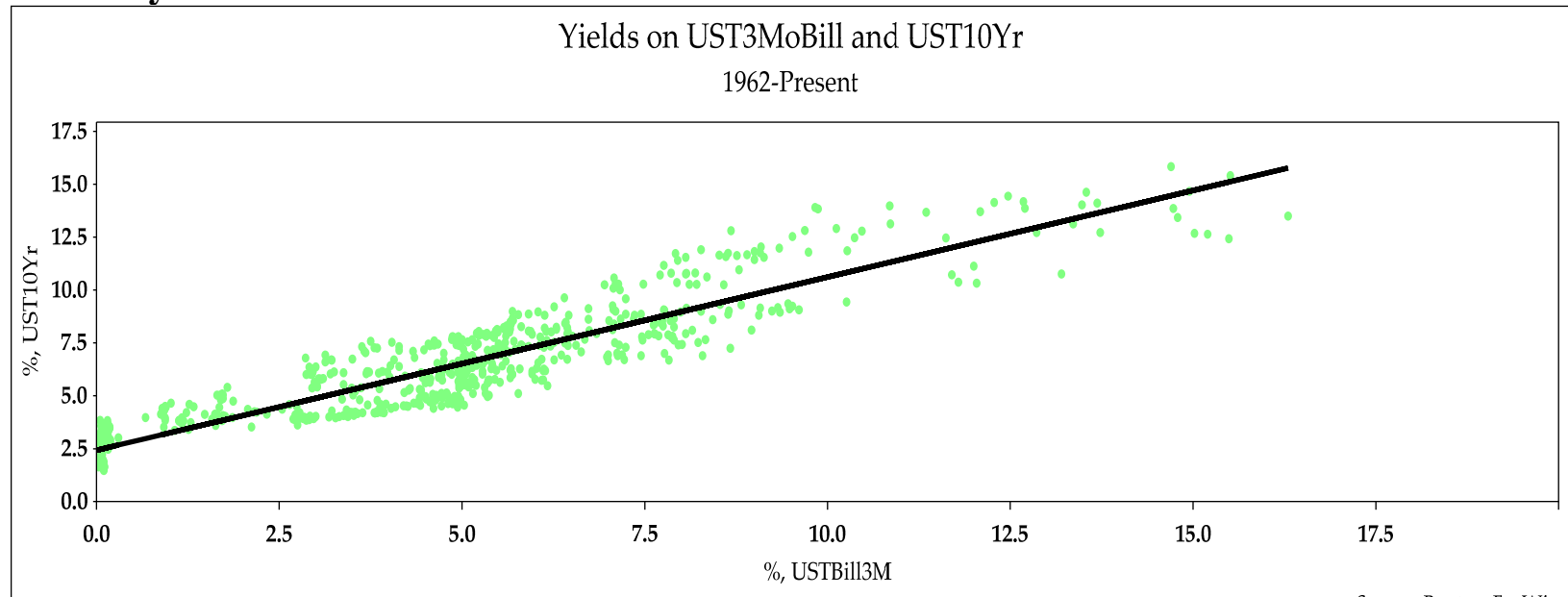

Figure 11b: Scatterplot of the Percentage Point Changes, Year over Year, in Yields of 10year US Treasury Securities and 3-month US Treasury Bills

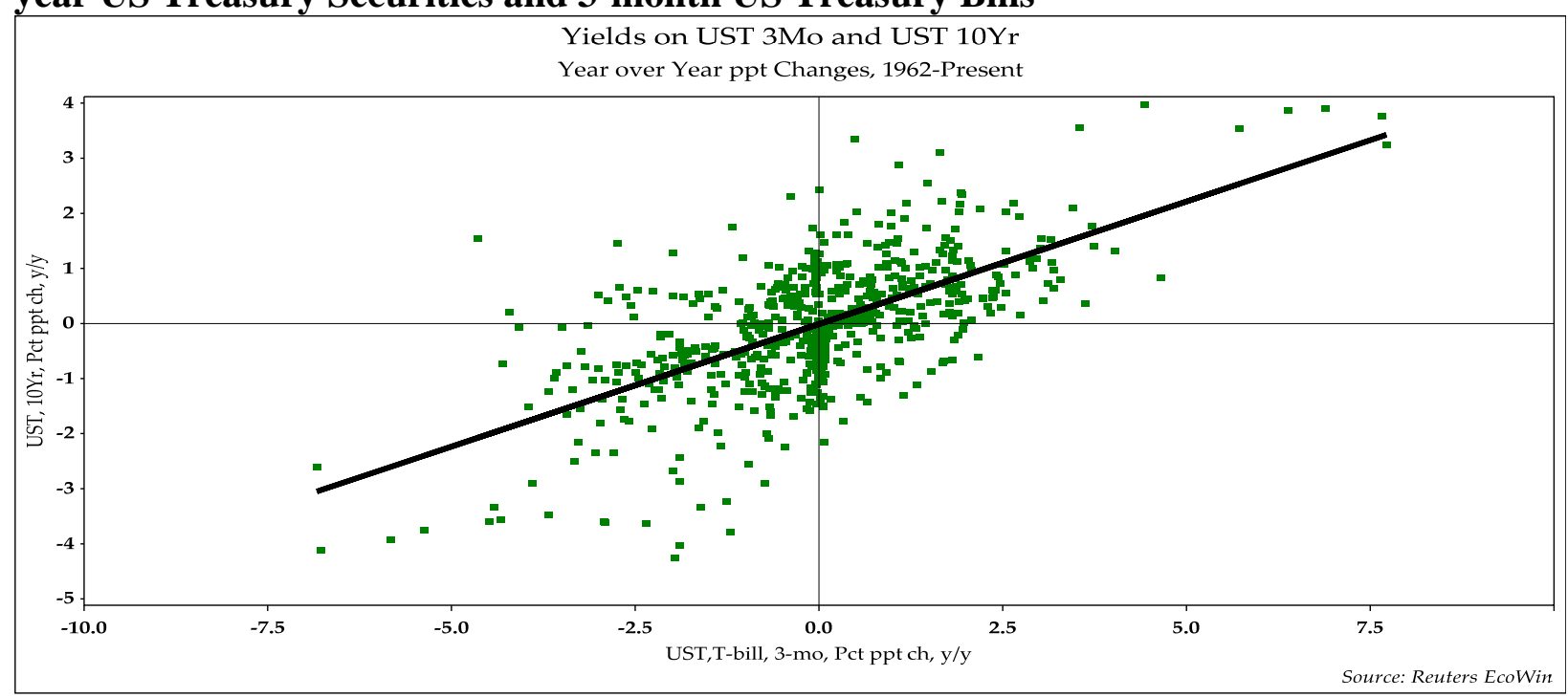

Figure 12a is a scatterplot of the yields of US Treasury securities of a 30-year tenor and 3-month US Treasury bills. Figure $12 \mathrm{~b}$ is a scatterplot of the percentage point changes, year over year, in the yields of US Treasury securities of a 30-year tenor and 3-month US Treasury bills. 
Figure 12a: Scatterplot of the Yields of 30-year US Treasury Securities and 3-month US Treasury Bills

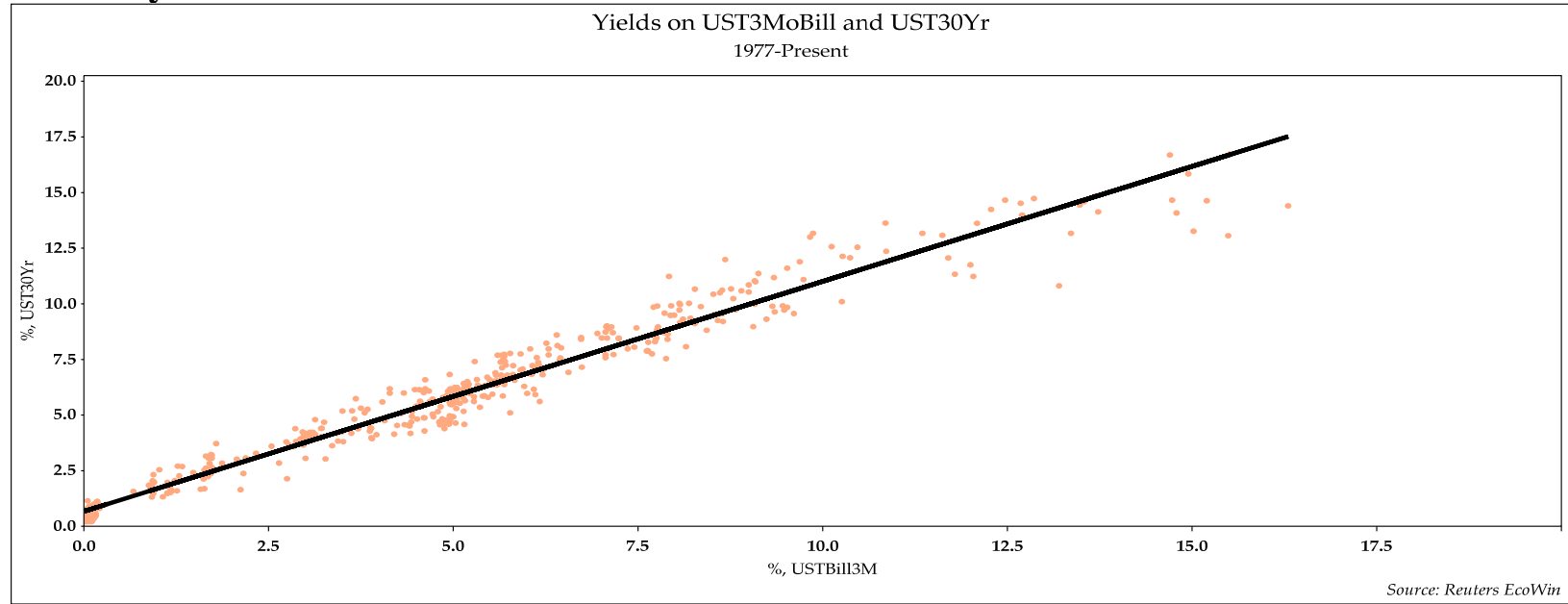

Figure 12b: Scatterplot of the Percentage Point Changes, Year over Year, in Yields of 30year US Treasury Securities and 3-month US Treasury Bills

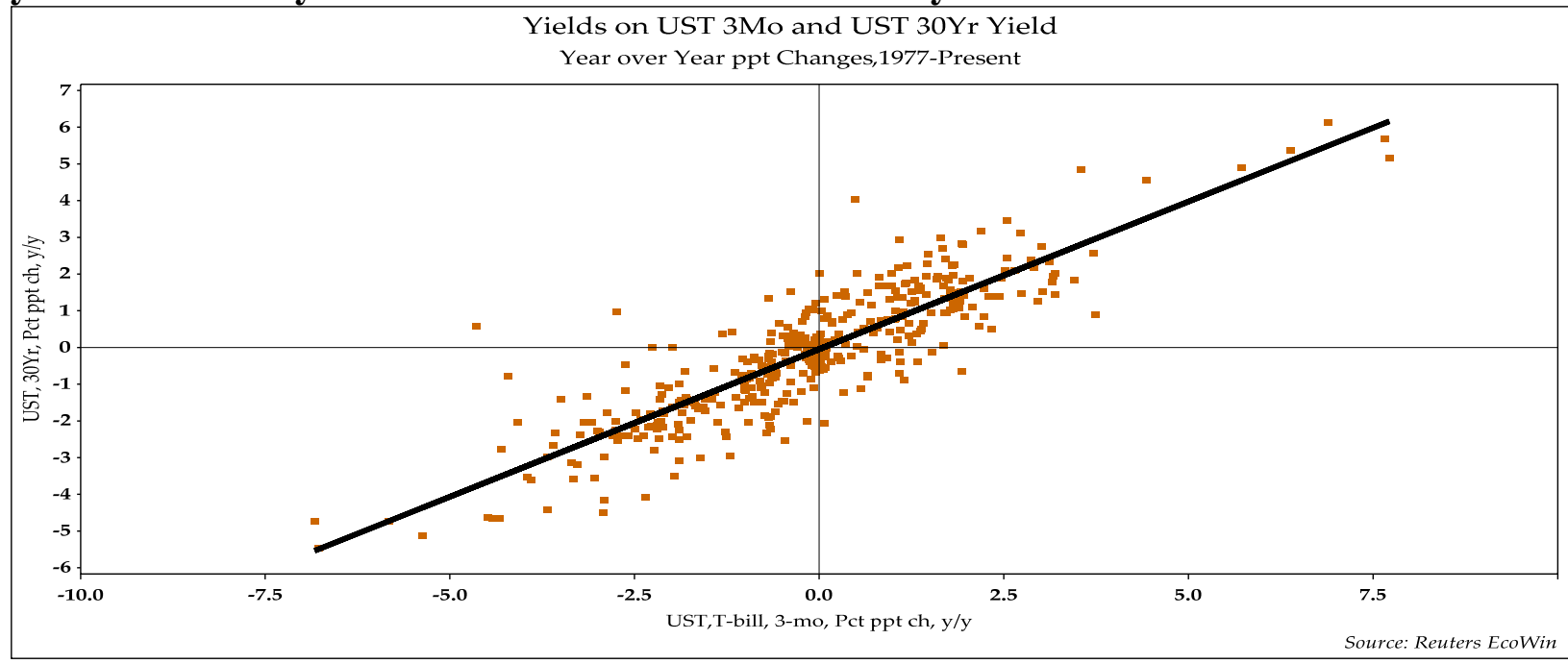

Figure 13 shows that US Treasury securities' nominal yields tend to move in tandem with various measures of the rates of core inflation. This is understandable as investors wish to be compensated for inflation or inflationary expectations. Generally nominal interest rates are higher than inflation or inflationary expectations. 
Figure 13: US Treasury Yields Tend to Move in Tandem with the Rates of Core Inflation

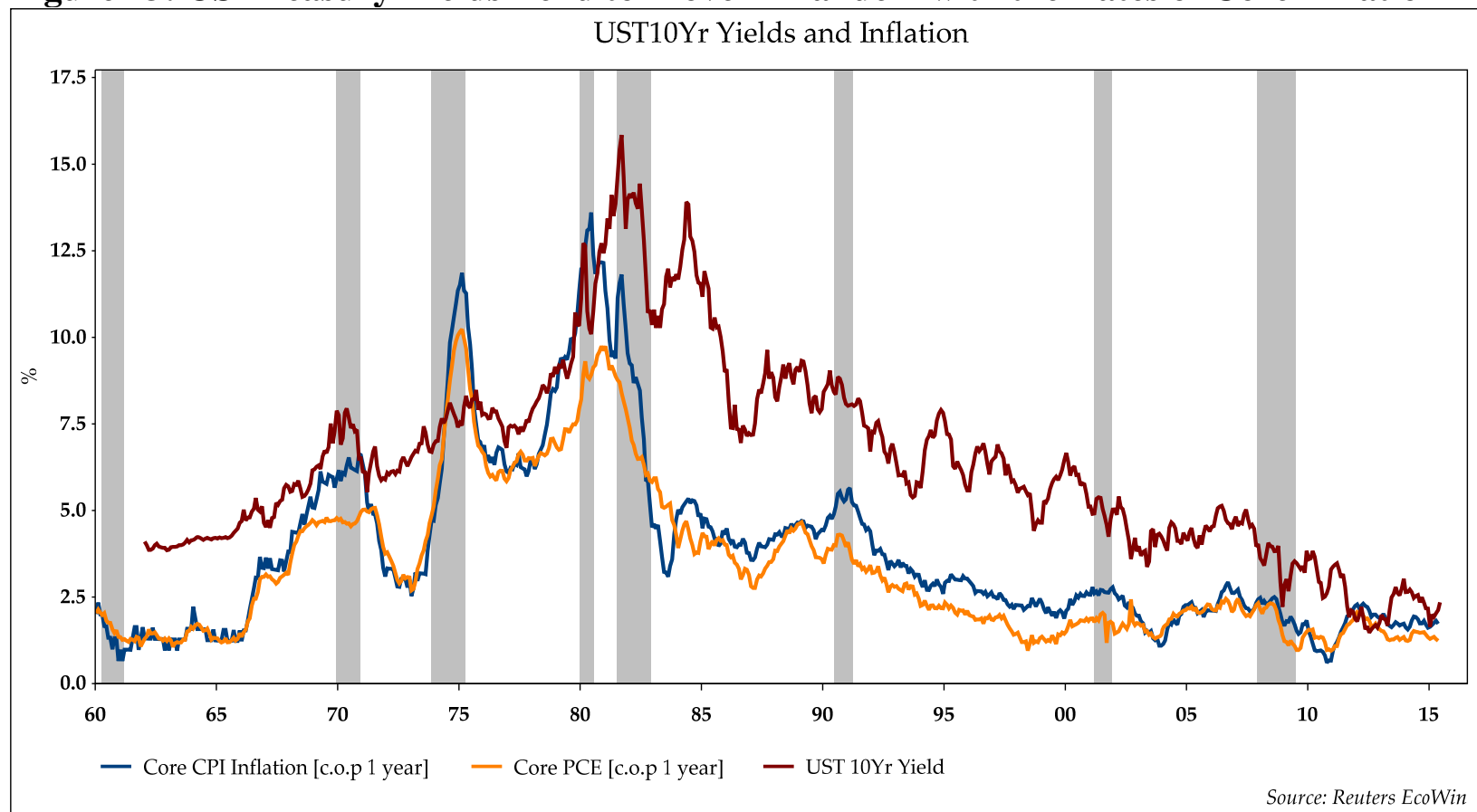

Figure 14a is a scatterplot demonstrating the strong correlation between the yields of 10 -year Treasury securities and the rate of core PCE inflation. Figure 14b is a scatterplot revealing the strong correlation between the yields of 10-year Treasury securities and the rate of core CPI inflation. 
Figure 14a: Scatterplot of the Yields of 10-year US Treasury Securities and Core PCE Inflation

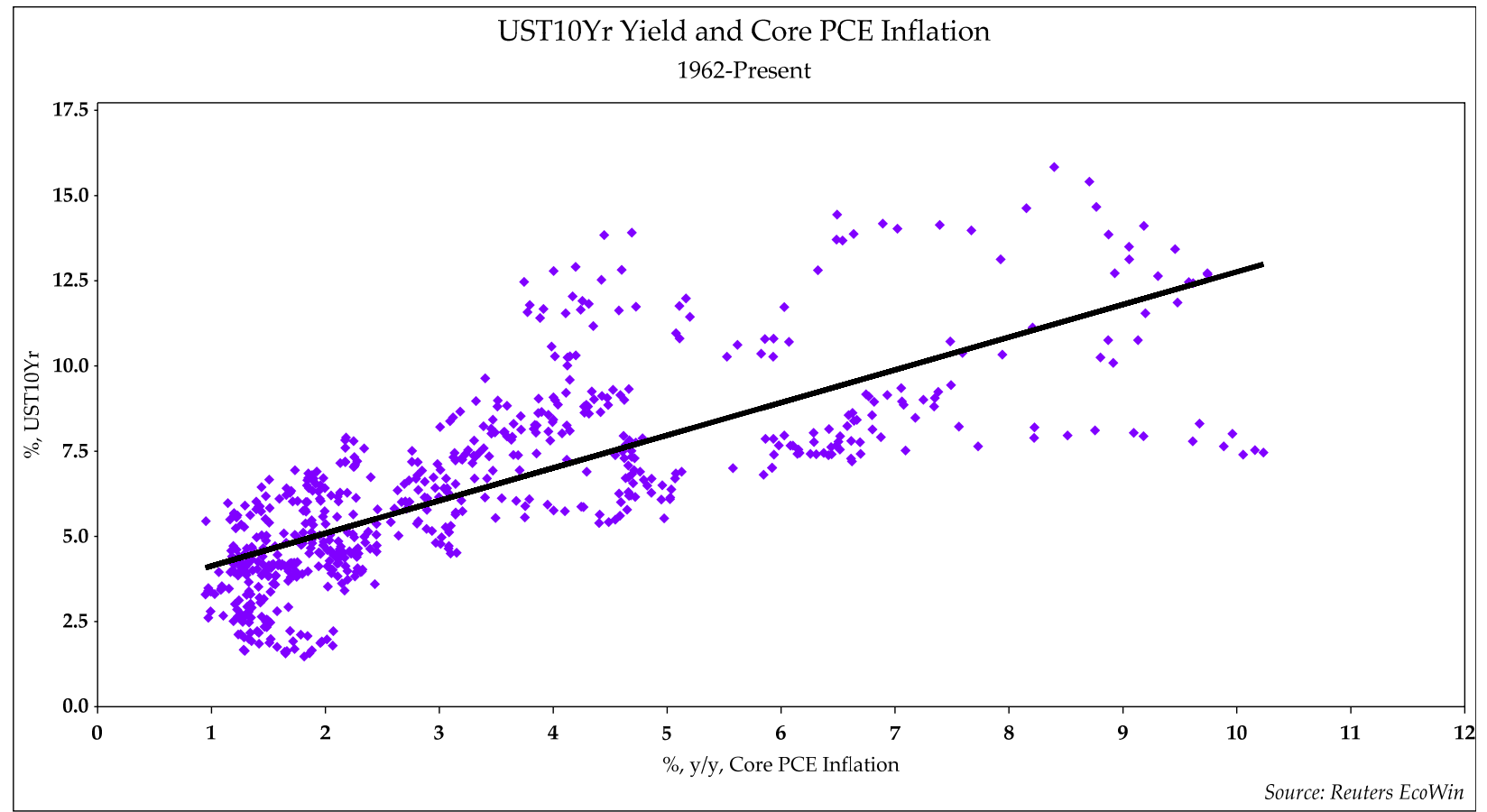

Figure 14b: Scatterplot of the Yields of 10-year US Treasury Securities and Core CPI Inflation

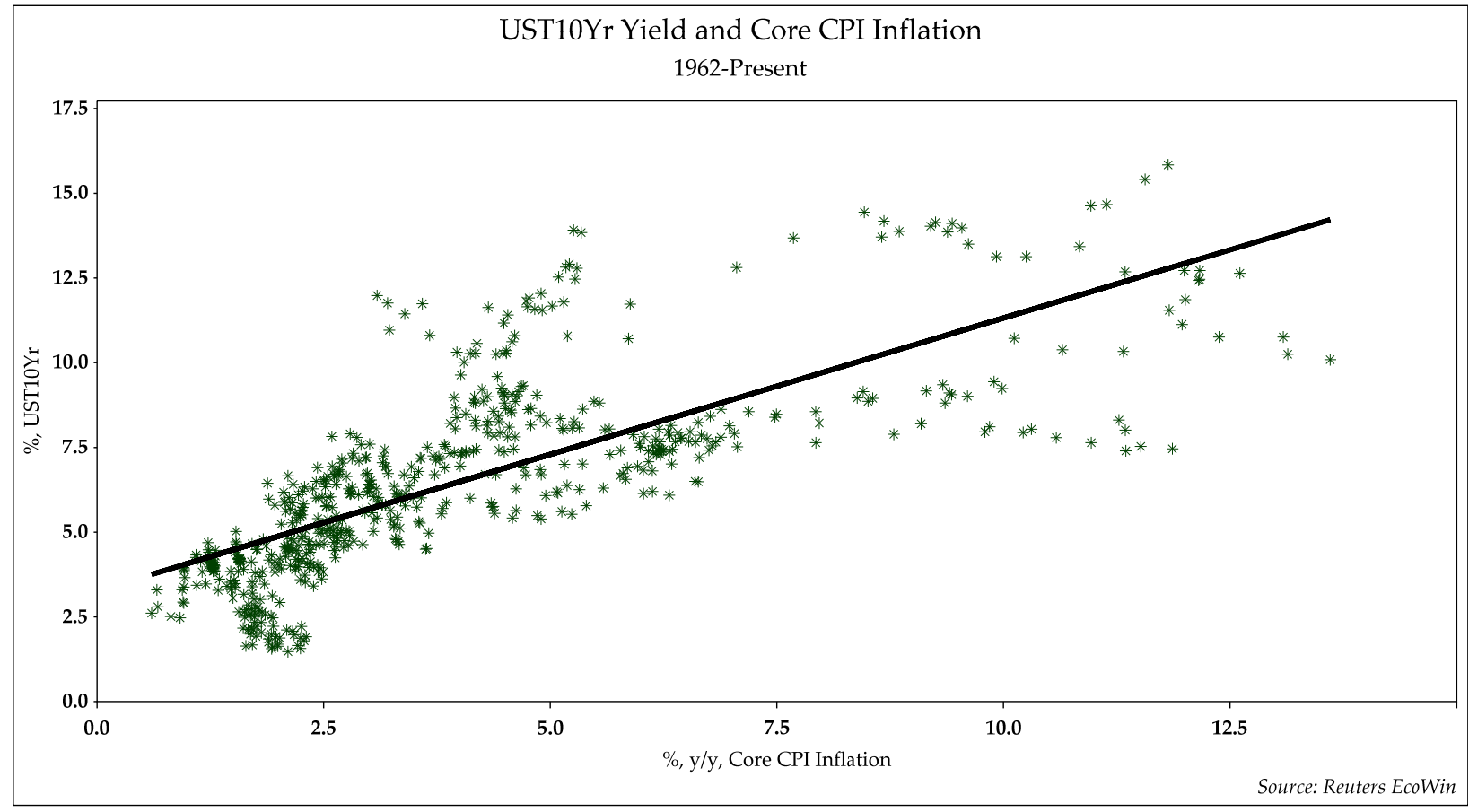




\section{SECTION III: KEYNES'S VIEW ON THE DRIVERS OF LONG-TERM INTEREST}

RATES

Keynes (2007 [1936]) recognized that the ultimate foundation of interest rates lies in human psychology, social convention, and liquidity preference. Nevertheless he maintained that in advanced capitalist countries with paper money, the central bank is the main driver of both shortterm interest rates on Treasury bills and the nominal yields on long-term government bonds. $\mathrm{He}$ also holds that the central bank influences the long-term interest rates on government bonds mainly through short-term interest rates and various monetary policy actions (Keynes 1930: 353; citied in Kregel 2011: 3). The short-term interest rates and the changes in short-term interest rates are the most important factors in determining long-term interest rates and changes in longterm interest rates. Keynes's analysis of the relationship between short-term interest rates and long-term interest rates drew on Winfried Riefler's (1930) pioneering empirical study of interest rates on US government securities. Keynes (1930: 359-62; cited in Kregel 2011: 4; Keynes 2007 [1936]: 152-53) is of the view that short-term realizations primarily drive the investor's longterm expectations because the investor often extrapolates the outlook for the future from the present situation and the past. The investor cannot estimate the mathematical expectations of the unknown and uncertain future. Thus, the investor has little choice other than inferring from the present condition.

Keynes resoundingly rejects the loanable funds theory of interest rates. For him, liquidity preference, which originates from psychological, social, and business incentives to liquidity, creates the foundation for the complex structure of interest rates as reflected on the yield curve for Treasury securities and various other fixed-income securities that prevail in the society. Other things held constant, the central bank exerts control on the "determinate rate of interest, or more strictly a determinate rate of interest for debts of different maturities" (Keynes 2007 [1936]: 204). He notes, in both the Treatise on Money and The General Theory, the close ties between short-term interest rates and long-term interest rates. He does acknowledge that while "the shortterm rate of interest is easily controlled by the monetary authority," that the long-term interest rate might be "more recalcitrant" to the central bank's action, particularly if it has fallen beyond some critical level, "which on the basis of past and present expectations of future monetary 
policy is considered 'unsafe' by representative opinion" (Keynes 2007 [1936]: 203). He emphasizes the public confidence in the credibility of the central bank is essential in affecting long-term interest rates.

Keynes argues that ontological uncertainty about the future implies that the investor's near-term conditions and views color their long-term views. As a result, the factors that affect current conditions and expectations regarding the near term also affect the long-term outlook. This is the key reason why long-term interest rates move largely in tandem with short-term interest rates. Those same factors that alter the near-term outlook and cause fluctuations in the short-term interest rates also induce similar changes in the investor's long-term outlook, which leads to fluctuations in long-term interest rates, mostly in accordance with the changes in short-term interest rates.

Keynes's view is that the key driver of the long-term interest rate is the short-term interest rate, which is primarily set by the central bank's actions. His view is concordant with the "chartalist" theory of modern money (Wray 2003, 2012; Tcherneva 2011; Tymoigne 2013), the analysis of the operational aspects of contemporary central banking (Bindseil 2004; Fullwiler 2008), and recent developments in mainstream macroeconomics and monetary theory (Sims 2013; Woodford 2001).

In contrast to Keynes's view, the conventional wisdom as expressed in the empirical literature on government bond yields, such as Baldacci and Kumar (2010), Gruber and Kamin (2012), Lam and Tokuoka (2011), Poghoysan (2012), and Tokuoka (2012), is that public financial variables have a decisive influence on government bonds' nominal yields. In the conventional view, increased (decreased) government indebtedness and the deterioration (improvement) of government fiscal deficits are associated with higher (lower) nominal yields on government bonds. 


\section{SECTION IV: A KEYNESIAN MODEL OF LONG-TERM INTEREST RATES AND CHANGES IN LONG-TERM INTEREST RATES}

A simple model of long-term interest rates and changes in long-term interest rates is presented here. It follows Keynes's views, as interpreted in Akram (2014) and Akram and Das (2014a, 2014b, 2015). The crucial institutional assumption in this model is of monetary sovereignty, as defined in Wray (2012) and articulated in Tymoigne (2013). A country with monetary sovereignty issues its own currency and the country's central bank can set the policy rate. The central bank controls the short-term interest rates through setting the policy rate and has the authority to use various other tools of monetary policy. These features of a central bank give it the operational ability to influence long-term interest rates. These characteristics of monetary sovereignty aptly describe the institutional settings of the US government, including the Federal Reserve, which has a wide range of tools to set policy rates, influence the short-term interest rates, and, if deemed necessary, even purchase long-term US Treasury securities, agency mortgage-backed securities (MBS), and a wide range of fixed-income assets from primary dealers in order to influence long-term interest rates and interest rate spreads.

The variables for the model are as follows: the long-term interest rate, $r_{L T}$; the short-term interest rate, $r_{S T}$; the policy rate, $r_{P}$; the spread between the short-term interest rate and the policy rate, $\tau$; the forward interest rates, $f_{S T, L T-S T}$; the future short-term interest rate, $r_{F}$; the term premium, $z$; the current inflation rate, $\pi$; the expected inflation rate, $\mathbb{E} \pi_{F}$; the current growth rate, $g$; the expected growth rate, $\mathbb{E} g_{F}$; and the government finance variable, $V$. The model is described below.

The long-term interest rate depends on the short-term interest rate and an appropriate forward rate (equation 4.1). Thus, the long-term interest rate is a function of the short-term interest rate and the appropriate forward rate (equation 4.2). The forward rate is a function of the future shortterm interest rate and the term premium (equation 4.3). But the function of the future short-term interest rate and the term premium, in turn, is equal to the function of expected inflation and the expected growth rate (equation 4.4). 
In a world characterized by rational expectations, the expected rate of inflation and the expected growth rate would respectively amount to the mathematical expectations of the possible growth rates and the possible rates of inflation in various states of the world. However, in a world characterized by ontological uncertainty, the probability of unknown events is incalculable. Hence, under a Keynesian perspective, the investor is forced take cues about the expected rate of inflation and the expected growth rate from the current conditions. Current inflation provides the best guess for the expected inflation (equation 4.5). Similarly current growth provides the best cue for the expected growth rate (equation 4.6). The forward rate, thus, is a function of the current inflation rate and the current growth rate (equation 4.7). The long-term interest rate depends on the short-term interest rates and the function of the drivers of the forward rate (equation 4.8). This implies that the long-term interest rate, under Keynesian assumptions, is a function of the short-term interest rate, current inflation, and the current growth rate (equation 4.9a). This also implies that the change in the long-term interest rate is a function of the change in the short-term interest rate, the change in current inflation, and the change in the growth rate (equation 4.9b).

If government finance variables are thought to affect long-term interest rates, perhaps through influencing the forward rate, then these factors could be incorporated as well. The long-term interest rate would then be a function of the short-term interest rate, current inflation, the current growth rate, and the government finance variable (equation 4.10a). Similarly the changes in the long-term interest rate would be a function of the changes in the above-mentioned independent variables (equation 4.10b).

The short-term interest rate depends on the policy rate set by the central bank and a spread (equation 4.11a). Likewise the changes in the short-term interest rate depend on the changes in the policy rate and the changes in the same spread (equation $4.11 \mathrm{~b}$ ). 
The model is expressed in the following system of equations:

$$
\begin{aligned}
& \text { [4.1] }\left(1+r_{L T}\right)^{L T}=\left(1+r_{S T}\right)\left(1+f_{S T, L T-S T}\right)^{L T-S T} \\
& \text { [4.2] } r_{L T}=F^{1}\left(r_{S T}, f_{S T, L T-S T}\right) \\
& \text { [4.3] } f_{S T, L T-S T}=F^{2}\left(r_{F}, z\right) \\
& \text { [4.4] } F^{2}\left(r_{F}, z\right)=F^{3}\left(\mathbb{E} \pi_{F}, \mathbb{E} g_{F}\right) \\
& \text { [4.5] } \mathbb{E} \pi_{F}=F^{4}(\pi) \\
& \text { [4.6] } \mathbb{E} g_{F}=F^{5}(g) \\
& \text { [4.7] } f_{S T, L T-S T}=F^{6}(\pi, g) \\
& \text { [4.8] } r_{L T}=F^{1}\left(r_{S T}, F^{6}(\pi, g)\right) \\
& \text { [4.9a] } r_{L T}=F^{7}\left(r_{S T}, \pi, g\right) \\
& \text { [4.9b] } \Delta r_{L T}=F^{8}\left(\Delta r_{S T}, \Delta \pi, \Delta g\right) \\
& \text { [4.10a] } r_{L T}=F^{9}\left(r_{S T}, \pi, g, V\right) \\
& \text { [4.10b] } \Delta r_{L T}=F^{10}\left(\Delta r_{S T}, \Delta \pi, \Delta g, \Delta V\right) \\
& \text { [4.11a] } r_{S T}=r_{P}+\tau \\
& \text { [4.11b] } \Delta r_{S T}=\Delta r_{P}+\Delta \tau
\end{aligned}
$$

\section{SECTION V: DATA}

Time series data on short-term interest rates, long-term interest rates, the rate of inflation, economic activity, and government finance are used here. Short-term interest rates are obtained from the nominal yields on US Treasury bills of a 3-month and 6-month tenor. Long-term interest rates are obtained from nominal yields of long-term US Treasury securities of various tenors, such as the yields of Treasury securities of 2-year, 5-year, 10-year, and 30-year tenors. Inflation data cover total inflation and core inflation. Core inflation is defined as total inflation minus food and energy inflation. Total inflation is measured by the percentage changes year over year in: (i) PCE inflation and (ii) CPI inflation, while core inflation is as measured by the percentage changes in: (i) core PCE inflation and (ii) core CPI inflation. Economic activity is measured by two variables: (i) the year-over-year percentage changes in the seasonally adjusted measure of the index of industrial production and (ii) the year-over-year percentage changes in the seasonally adjusted annualized rate of GDP. Government finance data cover federal debt as a share of nominal GDP, federal deficit as a share of nominal GDP, general government net 
borrowing/lending as a share of nominal GDP, general government gross liabilities as a share of nominal GDP, and general government net liabilities as a share of nominal GDP.

Table 1 summarizes the variables and data used in the econometric models. The first column gives the variable labels. The second column provides the variable description and the time range for the data. The third column gives the original frequency. It also states if the data have been converted to a lower frequency. The fourth column lists both the primary sources and the secondary sources. The final column lists the data provider's [Thomson Reuters EcoWin (various years)] mnemonic codes for the times series of the variables.

Table 1: Summary of the Data and the Variables

\begin{tabular}{|c|c|c|c|c|}
\hline $\begin{array}{l}\text { Variable } \\
\text { labels }\end{array}$ & Data description, date range & Frequency & Sources & $\begin{array}{l}\text { Thomson Reuters } \\
\text { EcoWin mnemonic } \\
\text { code }\end{array}$ \\
\hline \multicolumn{5}{|c|}{ Short-term interest rates } \\
\hline TB3M_Q & $\begin{array}{l}\text { Treasury bills, 3-month, bid, } \\
\text { yield, \%, average; } \\
\text { Jan 1960-Nov 2014; } \\
\text { 1Q1960-3Q2014 }\end{array}$ & $\begin{array}{l}\text { Monthly; } \\
\text { converted to } \\
\text { quarterly }\end{array}$ & $\begin{array}{l}\text { Federal Reserve: } \\
\text { Thomson } \\
\text { Reuters EcoWin }\end{array}$ & ew:usa14010 \\
\hline TB6M_Q & $\begin{array}{l}\text { Treasury bills, 6-month, bid, } \\
\text { yield, \%, average; } \\
\text { Jan 1960-Nov 2014; } \\
\text { 1Q1960-3Q2014 }\end{array}$ & $\begin{array}{l}\text { Daily; converted to } \\
\text { quarterly }\end{array}$ & $\begin{array}{l}\text { Federal Reserve: } \\
\text { Thomson } \\
\text { Reuters EcoWin }\end{array}$ & ew:usa14013 \\
\hline \multicolumn{5}{|c|}{ Long-term interest rates } \\
\hline UST2YR_Q & $\begin{array}{l}\text { Treasury Security, 2-year, bid, } \\
\text { yield, \%, average; } \\
\text { Jun 1976-Nov 2014; } \\
\text { 2Q1976-3Q2014 }\end{array}$ & $\begin{array}{l}\text { Daily; converted to } \\
\text { quarterly }\end{array}$ & $\begin{array}{l}\text { Reuters; } \\
\text { Thomson } \\
\text { Reuters EcoWin }\end{array}$ & ew:usa14110 \\
\hline UST5YR_Q & $\begin{array}{l}\text { Treasury Security, 5-year, bid, } \\
\text { yield, \%, average; } \\
\text { Jan 1962-Nov 2014; } \\
\text { 1Q1962-3Q2014 }\end{array}$ & $\begin{array}{l}\text { Daily; converted to } \\
\text { quarterly }\end{array}$ & $\begin{array}{l}\text { Reuters; } \\
\text { Thomson } \\
\text { Reuters EcoWin }\end{array}$ & ew:usa14120 \\
\hline UST10YR_Q & $\begin{array}{l}\text { Treasury security, 10-year, bid, } \\
\text { yield, \%; } \\
\text { Jan 1962-Nov 2014; } \\
\text { 1Q1962-3Q2014 }\end{array}$ & $\begin{array}{l}\text { Daily; converted to } \\
\text { quarterly }\end{array}$ & $\begin{array}{l}\text { Reuters; } \\
\text { Thomson } \\
\text { Reuters EcoWin }\end{array}$ & ew:usa14130 \\
\hline UST30YR_Q & $\begin{array}{l}\text { Treasury security, 30-year, bid, } \\
\text { yield, \%; } \\
\text { Mar 1977-Nov 2014; } \\
\text { 2Q1977-3Q2014 }\end{array}$ & $\begin{array}{l}\text { Daily; converted to } \\
\text { quarterly }\end{array}$ & $\begin{array}{l}\text { Reuters; } \\
\text { Thomson } \\
\text { Reuters EcoWin }\end{array}$ & ew:usa14140 \\
\hline
\end{tabular}




\begin{tabular}{|c|c|c|c|c|}
\hline $\begin{array}{l}\text { Variable } \\
\text { labels }\end{array}$ & Data description, date range & Frequency & Sources & $\begin{array}{l}\text { Thomson Reuters } \\
\text { EcoWin mnemonic } \\
\text { code }\end{array}$ \\
\hline \multicolumn{5}{|c|}{ U.S. Treasury securities, constant maturity yields } \\
\hline CMY2YR_Q & $\begin{array}{l}\text { Constant maturity yield, 2-year, } \\
\text { yield, \%, average; } \\
\text { Jan 1976-Nov 2014; } \\
\text { 1Q1976-3Q2014 }\end{array}$ & $\begin{array}{l}\text { Monthly; } \\
\text { converted to } \\
\text { quarterly }\end{array}$ & $\begin{array}{l}\text { Federal Reserve; } \\
\text { Thomson } \\
\text { Reuters EcoWin }\end{array}$ & ew:usa14025 \\
\hline CMY5YR_Q & $\begin{array}{l}\text { Constant maturity yield, 5-year, } \\
\text { yield, \%, average; } \\
\text { Jan 1960-Nov 2014; } \\
\text { 1Q1960-3Q2014 }\end{array}$ & $\begin{array}{l}\text { Monthly; } \\
\text { converted to } \\
\text { quarterly }\end{array}$ & $\begin{array}{l}\text { Federal Reserve: } \\
\text { Thomson } \\
\text { Reuters EcoWin }\end{array}$ & ew:usa14027 \\
\hline CMY10YR_Q & $\begin{array}{l}\text { Constant maturity yield, 10- } \\
\text { year, yield, \%, average; } \\
\text { Jan 1960-Nov 2014; } \\
\text { 1Q1960-3Q2014 }\end{array}$ & $\begin{array}{l}\text { Monthly; } \\
\text { converted to } \\
\text { quarterly }\end{array}$ & $\begin{array}{l}\text { Federal Reserve; } \\
\text { Thomson } \\
\text { Reuters EcoWin }\end{array}$ & ew:usa14020 \\
\hline CMY30YR_Q & $\begin{array}{l}\text { Constant maturity yield, 30- } \\
\text { year, yield, \%, average; } \\
\text { Feb 1977-Nov 2014; } \\
\text { 2Q1977-3Q2014 }\end{array}$ & $\begin{array}{l}\text { Monthly; } \\
\text { converted to } \\
\text { quarterly }\end{array}$ & $\begin{array}{l}\text { Federal Reserve: } \\
\text { Thomson } \\
\text { Reuters EcoWin }\end{array}$ & ew:usa14047 \\
\hline \multicolumn{5}{|l|}{ Inflation } \\
\hline PCE_YOY_Q & $\begin{array}{l}\text { Price Index, Personal } \\
\text { consumption expenditure, } \\
\text { overall, \% change, y/y; } \\
\text { Jan 1960-Oct 2014; } \\
\text { 1Q1960-3Q2014 }\end{array}$ & $\begin{array}{l}\text { Monthly; } \\
\text { converted to } \\
\text { quarterly }\end{array}$ & $\begin{array}{l}\text { Bureau of } \\
\text { Economic } \\
\text { Analysis; } \\
\text { Thomson } \\
\text { Reuters EcoWin }\end{array}$ & ew:usa12450 \\
\hline CPCE_YOY_Q; & $\begin{array}{l}\text { Price index, Personal } \\
\text { consumption expenditure ex } \\
\text { food and ex energy, \% change, } \\
\text { y/y; } \\
\text { Jan 1960-Oct 2014; } \\
\text { 1Q1960-3Q2014 }\end{array}$ & $\begin{array}{l}\text { Monthly; } \\
\text { converted to } \\
\text { quarterly }\end{array}$ & $\begin{array}{l}\text { Bureau of } \\
\text { Economic } \\
\text { Analysis; } \\
\text { Thomson } \\
\text { Reuters EcoWin }\end{array}$ & ew:usa12454 \\
\hline CPI_YOY_Q & $\begin{array}{l}\text { Consumer price index, total, \% } \\
\text { change, y/y; } \\
\text { Jan 1960-Oct 2014; } \\
\text { 1Q1960-3Q2014 }\end{array}$ & $\begin{array}{l}\text { Monthly; } \\
\text { converted to } \\
\text { quarterly }\end{array}$ & $\begin{array}{l}\text { Bureau of Labor } \\
\text { Statistics; } \\
\text { Thomson } \\
\text { Reuters EcoWin }\end{array}$ & ew:usa11801 \\
\hline CCPI_YOY_Q & $\begin{array}{l}\text { Consumer price index ex food } \\
\text { and ex energy, \% change, y/y; } \\
\text { Jan 1960-Oct 2014; } \\
\text { 1Q1960-3Q2014 }\end{array}$ & $\begin{array}{l}\text { Monthly; } \\
\text { converted to } \\
\text { quarterly }\end{array}$ & $\begin{array}{l}\text { Bureau of Labor } \\
\text { Statistics; } \\
\text { Thomson } \\
\text { Reuters EcoWin }\end{array}$ & ew:usa11806 \\
\hline \multicolumn{5}{|c|}{ Economic activity } \\
\hline IP_YOY_Q & $\begin{array}{l}\text { Industrial production, Volume, } \\
\text { Total, SA, Index, 2007=100, \% } \\
\text { change, y/y; } \\
\text { Jan 1960-Oct 2014; } \\
\text { 1Q1960-3Q2014 }\end{array}$ & $\begin{array}{l}\text { Monthly; } \\
\text { converted to } \\
\text { quarterly }\end{array}$ & $\begin{array}{l}\text { Federal Reserve; } \\
\text { Thomson } \\
\text { Reuters EcoWin }\end{array}$ & ew:usa02005 \\
\hline RGDP_YOY_Q & $\begin{array}{l}\text { Real Gross Domestic Product, } \\
\text { SA, \% change, y/y; } \\
\text { 1Q1960-3Q } 2014\end{array}$ & Quarterly & $\begin{array}{l}\text { Bureau of } \\
\text { Economic } \\
\text { Analysis; } \\
\text { Thomson } \\
\text { Reuters EcoWin }\end{array}$ & ew:usa01006 \\
\hline
\end{tabular}




\begin{tabular}{|c|c|c|c|c|}
\hline $\begin{array}{l}\text { Variable } \\
\text { labels }\end{array}$ & Data description, date range & Frequency & Sources & $\begin{array}{l}\text { Thomson Reuters } \\
\text { EcoWin mnemonic } \\
\text { code }\end{array}$ \\
\hline \multicolumn{5}{|c|}{ Government finance } \\
\hline G_DEBT_Q & $\begin{array}{l}\text { General government gross } \\
\text { financial liabilities, SA, \% of } \\
\text { nGDP; } \\
\text { 1Q1960-3Q2014 }\end{array}$ & Quarterly & $\begin{array}{l}\text { OECD Economic } \\
\text { Outlook; } \\
\text { Thomson } \\
\text { Reuters EcoWin }\end{array}$ & oe:usa_ggflqq \\
\hline N_DEBT_Q & $\begin{array}{l}\text { General government net } \\
\text { financial liabilities, SA, \% of } \\
\text { nGDP; } \\
\text { 1Q1960-3Q2014 }\end{array}$ & Quarterly & $\begin{array}{l}\text { OECD Economic } \\
\text { Outlook; } \\
\text { Thomson } \\
\text { Reuters EcoWin }\end{array}$ & oe:usa_gnflqq \\
\hline BORROW_Q & $\begin{array}{l}\text { General government net } \\
\text { lending, annualized rate, SA, \% } \\
\text { of nGDP; } \\
\text { 1Q1960-3Q2014 }\end{array}$ & Quarterly & $\begin{array}{l}\text { OECD Economic } \\
\text { Outlook; } \\
\text { Thomson } \\
\text { Reuters EcoWin }\end{array}$ & oe:usa_nlgqq \\
\hline DEBT_Q & $\begin{array}{l}\text { Federal debt outstanding, public } \\
\text { debt securities, as a \% of nGDP; } \\
\text { 1Q1960-3Q2014 }\end{array}$ & Quarterly & $\begin{array}{l}\text { Department of } \\
\text { Treasury, } \\
\text { Bureau of } \\
\text { Economic } \\
\text { Analysis; } \\
\text { Thomson } \\
\text { Reuters EcoWin }\end{array}$ & $\begin{array}{l}\text { ew:usa12651; } \\
\text { ew:usa01200 }\end{array}$ \\
\hline PDEBT_Q & $\begin{array}{l}\text { Total public debt, as \% of nGDP; } \\
\text { 1Q1966-3Q2014 }\end{array}$ & Quarterly & $\begin{array}{l}\text { Federal Reserve } \\
\text { Bank of St. } \\
\text { Louis; } \\
\text { Thomson } \\
\text { Reuters EcoWin }\end{array}$ & ew:usa12008346 \\
\hline BALANCE_Q & $\begin{array}{l}\text { Federal budget balance, as \% of } \\
\text { nGDP; } \\
\text { 1Q1960-4Q2013 }\end{array}$ & $\begin{array}{l}\text { Annual; converted } \\
\text { to quarterly }\end{array}$ & $\begin{array}{l}\text { Federal Reserve } \\
\text { Bank of St. } \\
\text { Louis; Thomson } \\
\text { Reuters EcoWin }\end{array}$ & ew:usa12008345 \\
\hline
\end{tabular}

\section{SECTION VI: EMPIRICAL APPROACH, FINDINGS, AND INTERPRETATIONS}

\subsection{Model Specification}

Macroeconomic time series studies can be divided into two general types: stationary and nonstationary time series models. The earlier studies mainly assume stationary variables and estimate the model by the classical methods of estimation. Since the variables in the model are non-stationary it becomes necessary to investigate the relationships under non-stationary cointegration for the study of the long-run economic relationship (such as the determinants of long-term interest rates). Consequently a vector error correction (VEC) model is applied here. 
The VEC model, as developed by Johansen $(1988,1991,1995)$, is used for the present analysis to examine the dynamic relationships among the variables - short-term interest rates $\left(r_{S T}\right)$, longterm interest rates $\left(r_{L T}\right)$, the rate of inflation $\left(\pi_{t}\right)$, economic activity $\left(g_{t}\right)$, and government finance $\left(V_{t}\right)$. Johansen's model has cointegration relationships built into the specification so that it restricts the long-run behavior of the endogenous variables from converging to their cointegrating relationships while allowing for short-run adjustment dynamics. Hence, this approach is relevant for the questions addressed in this paper.

Following Johansen's procedure, consider a vector autoregression (VAR) model, adapted to the VEC model representation, as given below:

$$
\Delta Z_{t}=C+\Gamma_{1} \Delta Z_{t-1}+\ldots+\Gamma_{k-t} \Delta Z_{t-k+1}+\Pi Z_{t-k}+e_{t} \quad \ldots \quad \ldots
$$

where $Z_{t}=\left(r_{L T}, r_{S T}\right)^{\prime}\left(\right.$ model1), or $Z_{t}=\left(r_{L T}, r_{S T}, V_{t}\right)^{\prime}(\operatorname{model} 2)$, or $Z_{t}=\left(r_{L T}, r_{S T}, \pi_{t}\right)^{\prime}$ (model3), or $Z_{t}=\left(r_{L T}, r_{S T}, \pi_{t}, V_{t}\right)^{\prime}(\operatorname{model} 4)$, while $\Gamma_{j} \Delta Z_{t-j}$ and $\Pi Z_{t-p}$ are the vector autoregressive component in first difference and error correction components, respectively. $C$ is an $(n \times 1)$ vector of constants, while $e_{t}$ is an $(n \times 1)$ vector of white-noise error terms. $\Gamma_{j}$ is an $(n \times n)$ matrix that stands for the short-term adjustment coefficients among variables with $(k-1)$ number of lags; $\Pi$ is an $(n \times n)$ matrix of parameters. As $\Pi=\alpha \beta^{\prime}$, where $\alpha$ is an $(n \times r)$ matrix that represents the speed of the adjustment coefficient of the error correction mechanism, while $\beta$ is an $(n \times r)$ matrix of cointegrating vectors. Under certain conditions, the $Z_{t}$ process is nonstationary, while both the first-differenced process $\Delta Z_{t}$ and the linear combinations $\beta^{\prime} Z_{t-1}$ are stationary. 


\subsection{Model Estimation}

The model estimation process comprises three parts: (1) testing for a unit root in each series; (2)

testing for the number of cointegrating vectors in the system, given that one cannot reject the null hypothesis of a unit root in the variables; and (3) estimating in the framework of a multivariate VEC model.

\subsection{Stationarity Tests}

To estimate the VEC model, the first step is to test for stationarity. The stationarity properties in the time series are substantiated by performing the Augmented Dickey-Fuller (ADF) (Dickey and Fuller 1979, 1981) and Phillips-Perron (PP) (Phillips and Perron 1988) tests. The tests are conducted on the variables in levels and first differences.

Tables $2 \mathrm{a}$ and $2 \mathrm{~b}$ present the unit root test results of the nominal yields of US Treasury bills of a 3-month tenor $\left(r_{S T}\right)$, the yields of Treasury securities of a 10-year tenor $\left(r_{L T}\right)$, the core PCE inflation $\left(\pi_{t}\right)$, the growth in the seasonally adjusted measure of the index of industrial production $\left(g_{t}\right)$, and the general government net financial liabilities as a share of nominal GDP $\left(V_{t}\right){ }^{1}$

\footnotetext{
${ }^{1}$ The results of the unit root tests on the nominal yields of US Treasury bills of a 6-month tenor are consistent with the nominal yields of US Treasury bills of a 3-month tenor. The results of the unit root tests on the growth of real GDP are consistent with the growth in the seasonally adjusted measure of the index of industrial production. The results of the unit root tests on the yields of Treasury securities of 2-year, 5-year, and 30-year tenors are consistent with the yields of Treasury securities of a 10-year tenor. The results of the unit root tests on PCE inflation, CPI inflation, and core CPI inflation are consistent with core PCE inflation. The results of the unit root tests on federal debt as a share of nominal GDP, federal deficit as a share of nominal GDP, general government gross liabilities as a share of nominal GDP, and general government net liabilities as a share of nominal GDP are consistent with the general government net borrowing/lending as a share of nominal GDP. Those results are provided in appendix tables $\mathrm{A} 1$ and $\mathrm{A} 2$.
} 
Table 2a: Unit-root Tests (Level)

\begin{tabular}{|c|c|c|c|c|c|}
\hline \multicolumn{6}{|c|}{ Table 2(a) } \\
\hline \multicolumn{6}{|c|}{ Unit-root tests (Level) } \\
\hline Variable & & Tests & Statistic & P-value & Obs. \\
\hline \multirow[t]{6}{*}{ TB3M_Q } & Trend & ADF & -1.964 & 0.6207 & 218 \\
\hline & & PP & -2.263 & 0.4548 & 218 \\
\hline & No trend & ADF & -1.439 & 0.5632 & 218 \\
\hline & & PP & -1.781 & 0.3900 & 218 \\
\hline & No trend & ADF & -1.062 & 0.5467 & 218 \\
\hline & no constant & PP & -1.189 & 0.3234 & 218 \\
\hline \multirow[t]{6}{*}{ CMY10YR_Q } & Trend & ADF & -2.923 & 0.1549 & 218 \\
\hline & & $\mathrm{PP}$ & -1.679 & 0.7601 & 218 \\
\hline & No trend & ADF & -0.992 & 0.7563 & 218 \\
\hline & & PP & -1.299 & 0.6295 & 218 \\
\hline & No trend & ADF & -0.646 & 0.3423 & 218 \\
\hline & no constant & $\mathrm{PP}$ & -0.721 & 0.4322 & 218 \\
\hline \multirow[t]{6}{*}{ CPCE_YOY_Q } & Trend & ADF & -1.575 & 0.8020 & 219 \\
\hline & & PP & -2.165 & 0.5097 & 219 \\
\hline & No trend & ADF & -1.023 & 0.7447 & 219 \\
\hline & & PP & -1.746 & 0.4077 & 219 \\
\hline & No trend & ADF & -0.710 & 0.6537 & 219 \\
\hline & no constant & $\mathrm{PP}$ & -1.049 & 0.3542 & 219 \\
\hline \multirow[t]{6}{*}{ IP_YOY_Q } & Trend & ADF & -3.857 & 0.0139 & 219 \\
\hline & & PP & -5.096 & 0.0001 & 219 \\
\hline & No trend & ADF & -3.825 & 0.0027 & 219 \\
\hline & & $\mathrm{PP}$ & -5.022 & 0.0000 & 219 \\
\hline & No trend & ADF & -3.286 & 0.0010 & 219 \\
\hline & no constant & PP & -4.294 & 0.0000 & 219 \\
\hline \multirow[t]{6}{*}{ N_DEBT_Q } & Trend & ADF & -0.102 & 0.9930 & 215 \\
\hline & & PP & -0.630 & 0.9774 & 215 \\
\hline & No trend & ADF & 1.954 & 0.9986 & 215 \\
\hline & & PP & 0.808 & 0.9918 & 215 \\
\hline & No trend & ADF & 2.046 & 0.6350 & 215 \\
\hline & no constant & PP & 1.231 & 0.3410 & 215 \\
\hline
\end{tabular}

Note: PP test, $\mathrm{ADF}$ test $\left(\mathrm{H}_{0}\right.$ : Series has a unit root) 
Table 2b: Unit-root Tests (Difference)

\begin{tabular}{|c|c|c|c|c|c|}
\hline \multicolumn{6}{|c|}{ Table 2(b) } \\
\hline \multicolumn{6}{|c|}{ Unit-root tests (Difference) } \\
\hline Variable & & Tests & Statistic & P-value & Obs. \\
\hline \multirow[t]{6}{*}{$\Delta$ (TB3M_Q) } & Trend & ADF & -5.880 & 0 & 217 \\
\hline & & $\mathrm{PP}$ & -5.035 & 0 & 217 \\
\hline & No trend & ADF & -5.646 & 0 & 217 \\
\hline & & PP & -4.977 & 0 & 217 \\
\hline & No trend & ADF & -5.648 & 0 & 217 \\
\hline & no constant & $\mathrm{PP}$ & -4.988 & 0 & 217 \\
\hline \multirow[t]{6}{*}{$\Delta$ (CMY10YR_Q) } & Trend & ADF & -11.609 & 0 & 217 \\
\hline & & $\mathrm{PP}$ & -11.577 & 0 & 217 \\
\hline & No trend & ADF & -11.536 & 0 & 217 \\
\hline & & $\mathrm{PP}$ & -11.523 & 0 & 217 \\
\hline & No trend & ADF & -11.560 & 0 & 217 \\
\hline & no constant & $\mathrm{PP}$ & -11.548 & 0 & 217 \\
\hline \multirow[t]{6}{*}{$\Delta$ (CPCE_YOY_Q) } & Trend & ADF & -5.198 & 0 & 218 \\
\hline & & $\mathrm{PP}$ & -4.733 & 0 & 218 \\
\hline & No trend & ADF & -4.966 & 0 & 218 \\
\hline & & PP & -4.698 & 0 & 218 \\
\hline & No trend & ADF & -4.979 & 0 & 218 \\
\hline & no constant & PP & -4.705 & 0 & 218 \\
\hline \multirow[t]{6}{*}{$\Delta$ (IP_YOY_Q) } & Trend & ADF & -5.797 & 0 & 218 \\
\hline & & PP & -4.305 & 0 & 218 \\
\hline & No trend & ADF & -5.791 & 0 & 218 \\
\hline & & PP & -4.311 & 0 & 218 \\
\hline & No trend & ADF & -5.803 & 0 & 218 \\
\hline & no constant & PP & -4.321 & 0 & 218 \\
\hline \multirow[t]{6}{*}{$\Delta$ (N_DEBT_Q) } & Trend & ADF & -12.594 & 0 & 214 \\
\hline & & PP & -13.232 & 0 & 214 \\
\hline & No trend & ADF & -11.844 & 0 & 214 \\
\hline & & PP & -12.571 & 0 & 214 \\
\hline & No trend & ADF & -11.757 & 0 & 214 \\
\hline & no constant & PP & -12.491 & 0 & 214 \\
\hline
\end{tabular}

Note: PP test, ADF test $\left(\mathrm{H}_{0}\right.$ : Series has a unit root) 
Based on the unit root tests as depicted in tables $2 \mathrm{a}$ and $2 \mathrm{~b}$, all unit root tests yield remarkably similar results for variables $r_{L T}, r_{S T}, \pi_{t}$, and $V_{t}$ which are non-stationary in their levels but become stationary in their first differences. Thus, it can be concluded that those four series are I(1) at the $5 \%$ level of significance. However, the application of the ADF and PP tests for $g_{t}$ revealed that this variable is stationary in both its levels and its first differences.

\subsection{Cointegration Tests}

Johansen and Juselius's (1990) cointegration method was used for the cointegration analysis. Treating $r_{L T}, r_{S T}, \pi_{t}$, and $V_{t}$ as nonstationary variables, table 3 presents test statistics for determining whether $r_{L T}$ is cointegrated with any of these variables.

To analyze the cointegration relationships among the variables, seven VAR models are defined. These $\operatorname{are}\left(r_{L T}, r_{S T}\right),\left(r_{L T}, \pi_{t}\right),\left(r_{L T}, V_{t}\right),\left(r_{L T}, \pi_{t}, V_{t}\right),\left(r_{L T}, r_{S T}, \pi_{t}\right),\left(r_{L T}, r_{S T}, V_{t}\right)$, and $\left(r_{L T}, r_{S T}, \pi_{t}, V_{t}\right) .^{2}$ The results based on VARs are generally found to be sensitive to the lag length used and ordering of the variables. Thus, before determining the number of cointegrating vectors, lag lengths were chosen by Akaike's information criterion (AIC), Schwarz's Bayesian information criterion (SBIC), and the Hannan and Quinn information criterion (HQIC). A sequence of likelihood-ratio test statistics is also used to determine the lag length. The results suggest models with two variables - $\left(r_{L T}, r_{S T}\right),\left(r_{L T}, \pi_{t}\right)$, and $\left(r_{L T}, V_{t}\right)$ - are explained by eight lags, while the other four models with three or four variables are explained by six lags. Once the number of lags has been determined, the next task is to test for cointegration amongst the variables.

The Johansen cointegration test uses two statistical tests, namely the trace test and the likelihood eigenvalue test; both tests are reported in table 3. The first row $(r=0)$ tests the null hypothesis of no cointegration, the second row $(r=1)$ tests the null hypothesis of one cointegration relationship, and so on, all against the alternative of the full rank of cointegration. The trace test

\footnotetext{
${ }^{2}$ Since $g_{t}$ is a stationary variable, it is not included in the cointegration test.
} 
starts with $(r=0)$ and moves upwards. The process is stopped the first time the null hypothesis cannot be rejected. For instance, in the case of $r_{L T}, r_{S T}$, the hypothesis of $(r=0)$ is rejected, as the computed value of the test statistic (27.1912) is greater than the critical value (20.04). However, in the next step, the null hypothesis of at most one cointegrating vector cannot be rejected at the $10 \%$ level of significance. Thus, there is evidence of one cointegrating vector in the system. The maximum eigenvalue test provides more conclusive evidence regarding the exact number of cointegrating vectors in the system. The results again confirm that there is one cointegrating vector $(0.8414<6.65)$. Based on these results it can be said that there is one common permanent component driving the entire system of $\left(r_{L T}, r_{S T}\right)$.

The results for $\left(r_{L T}, \pi_{t}\right),\left(r_{L T}, r_{S T}, \pi_{t}\right),\left(r_{L T}, r_{S T}, V_{t}\right)$, and $\left(r_{L T}, r_{S T}, \pi_{t}, V_{t}\right)$ also suggest that there is one cointegrating equation in each case. These results indicate that $r_{L T}$ is cointegrated with $r_{S T}$ and $\pi_{t}$ but not with $V_{t}$. That is, the long-term interest rate stochastically co-moves with the short-term interest rate and the rate of inflation, but not with the government finance variable. ${ }^{3}$

\footnotetext{
${ }^{3}$ The Johansen cointegration test on various other long-term interest rates produces similar results with the yields of Treasury securities of a 10-year tenor. Those results are provided in appendix tables A3, A4, A5, A6, A7, A8, and A9.
} 
Table 3: Multivariate Cointegration Tests

\begin{tabular}{|c|c|c|c|c|c|}
\hline \multicolumn{6}{|c|}{$\begin{array}{r}\text { Table } 3 \\
\end{array}$} \\
\hline \multicolumn{6}{|c|}{ Multi-variate Cointegration Tests } \\
\hline \multicolumn{3}{|c|}{ Trace Test } & \multicolumn{3}{|c|}{ Maximum Eigenvalue Test } \\
\hline \multicolumn{2}{|c|}{ Null hypo. Test Statistic } & Critical Value & Null hypo. & Test Statistic & Critical Value \\
\hline \multicolumn{6}{|c|}{ (CMY10YR_Q, TB3M_Q) } \\
\hline$r=0$ & 27.1912 & 20.04 & $r=0$ & 26.3499 & 18.63 \\
\hline r\#1 & $0.8414 *$ & 6.65 & $\mathrm{r} \# 1$ & 0.8414 & 6.65 \\
\hline \multicolumn{6}{|c|}{ (CMY10YR_Q,CPCE_YOY_Q) } \\
\hline$r=0$ & 21.7197 & 20.04 & $r=0$ & 16.2729 & 18.63 \\
\hline r\#1 & $5.4468 *$ & 6.65 & $\mathrm{r} \# 1$ & 5.4468 & 6.65 \\
\hline \multicolumn{6}{|c|}{ (CMY10YR_Q, N_DEBT_Q) } \\
\hline$r=0$ & $4.7535^{*}$ & 20.04 & $r=0$ & 4.4725 & 18.63 \\
\hline $\mathrm{r} \# 1$ & 0.281 & 6.65 & r\#1 & 0.281 & 6.65 \\
\hline \multicolumn{6}{|c|}{ (CMY10YR_Q, N_DEBT_Q,CPCE_YOY_Q) } \\
\hline$r=0$ & $24.8691 *$ & 35.65 & $r=0$ & 15.1354 & 25.52 \\
\hline $\mathrm{r} \# 1$ & 9.7337 & 20.04 & $\mathrm{r} \# 1$ & 6.6881 & 18.63 \\
\hline $\mathrm{r} \# 2$ & 3.0456 & 6.65 & r\#2 & 3.0456 & 6.65 \\
\hline \multicolumn{6}{|c|}{ (CMY10YR_Q, TB3M_Q,CPCE_YOY_Q) } \\
\hline$r=0$ & 54.7434 & 35.65 & $r=0$ & 37.3605 & 25.52 \\
\hline r\#1 & $17.3830 *$ & 20.04 & r\#1 & 13.4271 & 18.63 \\
\hline r\#2 & 3.9559 & 6.65 & $\mathrm{r} \# 2$ & 3.9559 & 6.65 \\
\hline \multicolumn{6}{|c|}{ (CMY10YR_Q, TB3M_Q, N_DEBT_Q) } \\
\hline$r=0$ & 60.8477 & 35.65 & $r=0$ & 51.8328 & 25.52 \\
\hline r\#1 & $9.0148^{*}$ & 20.04 & r\#1 & 8.5402 & 18.63 \\
\hline r\#2 & 0.4746 & 6.65 & $\mathrm{r} \# 2$ & 0.4746 & 6.65 \\
\hline \multicolumn{6}{|c|}{ (CMY10YR_Q, TB3M_Q, CPCE_YOY_Q, N_DEBT_Q) } \\
\hline$r=0$ & 74.2672 & 54.46 & $r=0$ & 50.1238 & 32.24 \\
\hline r\#1 & $24.1434 *$ & 35.65 & r\#1 & 14.9672 & 25.52 \\
\hline $\mathrm{r} \# 2$ & 9.1761 & 20.04 & r\#2 & 7.3437 & 18.63 \\
\hline$r \# 3$ & 1.8325 & 6.65 & $r \# 3$ & 1.8325 & 6.65 \\
\hline
\end{tabular}

Notes: $1 .{ }^{*}$ indicate significance at the $10 \%$ level; $2 . r$ denotes the number of cointegrated vectors; 3 . AIC and SBIC criterion are used for the order of the VAR model 


\subsection{Vector Error Correction Model}

Given the cointegration results, the next stage in the model estimation process requires the fitting of a multivariate VEC model where the time series are found to be cointegrated. Table 4 presents the estimation of the corresponding VEC systems for four models $-Z_{t}=\left(r_{L T}, r_{S T}\right)^{\prime}(\operatorname{model} 1)$, $Z_{t}=\left(r_{L T}, r_{S T}, \pi_{t}\right)^{\prime}(\operatorname{model} 2), Z_{t}=\left(r_{L T}, r_{S T}, V_{t}\right)^{\prime}(\operatorname{model} 3)$, and $Z_{t}=\left(r_{L T}, r_{S T}, \pi_{t}, V_{t}\right)^{\prime}(\operatorname{model} 4)$ assuming one cointegrating relationship. For each model, data from two sets of long-term interest rates, namely $\triangle \mathrm{CMY10YR} \_\mathrm{Q}$ and $\triangle \mathrm{UST} 10 \mathrm{YR} \_\mathrm{Q}$, are used to check the robustness of the results. 4

First, the long-term interest rates are regressed only on the short-term interest rates (model 1). The coefficient is highly significant and suggests that an increase in the short-term interest rates by one basis point increases long-term interest rates by 97.7 basis points. The addition of the other variables, one by one, leaves the coefficients on the short-term interest rates always highly significant, but its size changes across different models. The government finance variable is never significant, suggesting that government finance has no significant $(10 \%)$ influence on long-term interest rates.

In general, the normalized cointegrating equation shows that, in the long run, there is a clear and reliable positive relationship between short-term and long-term interest rates. Turning to the parameter estimates of long-run relationships, long-run coefficients remain quite large and are statistically significant in all models. This result indicates that (stationary) movements in shortterm interest rates can have substantial effects on long-term interest rates.

\footnotetext{
${ }^{4}$ The results of all other long-term interest rates are provided in appendix tables A10, A11, A12, A13, A14, and A15.
} 
Table 4: Johansen VEC Model

\begin{tabular}{|c|c|c|c|c|c|c|c|c|}
\hline \multicolumn{9}{|c|}{ Table 4} \\
\hline \multicolumn{9}{|c|}{ Johansen VEC Model } \\
\hline & \multicolumn{4}{|c|}{ With CMY10YR_Q } & \multicolumn{4}{|c|}{ With UST10YR_Q } \\
\hline & Model 1 & Model 2 & Model 3 & Model 4 & Model 1' & Model 2' & Model 3' & Model 4' \\
\hline \multicolumn{9}{|c|}{ Long-run relationship } \\
\hline \multirow[t]{2}{*}{ TB3M_Q } & $-0.977 * * *$ & $-0.732 * * *$ & $-1.071 * * *$ & $-1.088 * * *$ & $-0.971 * * *$ & $-0.734 * * *$ & $-1.078 * * *$ & $-1.09 * * *$ \\
\hline & {$[0.073]$} & {$[0.08]$} & {$[0.069]$} & {$[0.08]$} & {$[0.074]$} & {$[0.085]$} & {$[0.071]$} & {$[0.081]$} \\
\hline \multirow[t]{2}{*}{ CPCE_YOY_Q } & & $-0.339 * *$ & & 0.098 & & $-0.328^{* *}$ & & 0.099 \\
\hline & & {$[0.118]$} & & {$[0.094]$} & & {$[0.119]$} & & {$[0.096]$} \\
\hline \multirow[t]{2}{*}{ N_DEBT_Q } & & & -0.014 & -0.008 & & & -0.014 & -0.008 \\
\hline & & & {$[0.015]$} & {$[0.014]$} & & & {$[0.015]$} & [0.014] \\
\hline CONSTANT & -1.67 & -1.667 & -0.255 & -0.756 & -1.709 & -1.711 & -0.185 & -0.723 \\
\hline \multicolumn{9}{|c|}{ Error correction terms } \\
\hline \multirow[t]{2}{*}{$\Delta($ CMY10YR_Q)(-1) } & $-0.070^{*}$ & $-0.126 * * *$ & $-0.058^{*}$ & $-0.063^{*}$ & & & & \\
\hline & {$[0.03]$} & {$[0.03]$} & {$[0.03]$} & {$[0.03]$} & & & & \\
\hline \multirow[t]{2}{*}{$\Delta$ (UST10YR_Q)(-1) } & & & & & $-0.072^{*}$ & $-0.128 * * *$ & $-0.057^{*}$ & $-0.062^{*}$ \\
\hline & & & & & {$[0.03]$} & {$[0.03]$} & {$[0.03]$} & {$[0.03]$} \\
\hline \multirow[t]{2}{*}{$\Delta($ TB3M_Q)(-1) } & 0.072 & 0.026 & $0.122^{* *}$ & $0.135^{* *}$ & 0.072 & -0.02 & $0.123^{* *}$ & $0.136^{* *}$ \\
\hline & {$[0.04]$} & {$[0.05]$} & {$[0.04]$} & {$[0.04]$} & {$[0.04]$} & {$[0.05]$} & {$[0.04]$} & {$[0.05]$} \\
\hline \multirow[t]{2}{*}{$\Delta$ (CPCE_YOY_Q)(-1) } & & -0.011 & & -0.025 & & -0.012 & & -0.025 \\
\hline & & {$[0.02]$} & & {$[0.02]$} & & {$[0.02]$} & & {$[0.02]$} \\
\hline \multirow[t]{2}{*}{$\Delta$ (N_DEBT_Q)(-1) } & & & $0.379 * * *$ & $0.410 * * *$ & & & $0.379 * * *$ & $0.412 * * *$ \\
\hline & & & {$[0.08]$} & {$[0.08]$} & & & {$[0.08]$} & {$[0.08]$} \\
\hline \multicolumn{9}{|c|}{ Diagnostics } \\
\hline Obs. & 216 & 216 & 213 & 213 & 208 & 208 & 205 & 205 \\
\hline Lags & 3 & 3 & 6 & 6 & 3 & 3 & 6 & 6 \\
\hline AIC & 2.935 & 3.136 & 5.919 & 5.983 & 3.012 & 3.251 & 6.021 & 5.899 \\
\hline Log Likelihood & -303.952 & -312.685 & -577.362 & -546.179 & -300.334 & -312.058 & -564.189 & -536.76 \\
\hline Chi2 & 159.828 & 234.226 & 724.659 & 737.502 & 151.279 & 220.791 & 680.089 & 693.12 \\
\hline LM(1) & 21.487 & 24.303 & 9.377 & 22.976 & 20.725 & 27.656 & 8.602 & 21.788 \\
\hline P-value & 0.0003 & 0.004 & 0.403 & 0.114 & 0.0003 & 0.001 & 0.475 & 0.15 \\
\hline LM(2) & 15.717 & 21.72 & 14.168 & 21.288 & 16.702 & 22.3285 & 13.708 & 20.335 \\
\hline P-value & 0.003 & 0.01 & 0.116 & 0.168 & 0.002 & 0.008 & 0.133 & 0.206 \\
\hline Skewness test & 4.876 & 3.476 & 60.168 & 53.761 & 4.08 & 2.85 & 56.842 & 57.371 \\
\hline P-value & 0.087 & 0.324 & 0 & 0 & 0.13 & 0.415 & 0 & 0 \\
\hline Highest modulus & 0.843 & 0.827 & 0.91 & 0.925 & 0.84351 & 0.825 & 0.911 & 0.922 \\
\hline
\end{tabular}

Notes: $1 .{ }^{* * *}$ significant at $1 \%$ level of significance, ${ }^{* *}$ significant at $5 \%$ level of significance, $*$ significant at $10 \%$ level of significance; 2. $\operatorname{LM}(\mathrm{j})$ is a test for no autocorrelation up to order $j$ 


\subsection{Diagnostic Tests}

Diagnostic tests are performed to check the signs of misspecification, like serial correlation or non-normality. A VAR version of the Lagrange multiplier test for serial correlation in the residual is implemented. This test examines up to the second order serial corrlation. Besides model 1 (with a P-value of 0.0003 ), one cannot reject the null hypothesis that there is no serial correlation.

The results of the skewness test do not suggest non-normality for model 1 and model 2 (with Pvalues ranging from 0.09 to 0.42 ), while for model 3 and model 4 the results imply that the errors are not normally distributed (with zero P-values). ${ }^{5}$ Furthermore, the eigenvalue stability conditions in the VEC models are checked. ${ }^{6}$ The results show that the highest modulus from model 1 and model 2 are around 0.83 , while the highest modulus from model 3 and model 4 are around 0.92 . Thus, the stability check indicates that the specifications of model 1 and model 2 represent a more stable process than model 3 and model 4. Overall, the residual diagnostics reveal no signs of misspecification like serial correlation, non-normality, or instability for model 2. Thus, model 2 is treated here as a baseline model for further examination.

\subsection{Interpretation of VEC Model Results}

From model 2, normalizing with respect to the coefficient of $r_{L T}$, the cointegrating vectors associated with the largest eigenvalues yield the following cointegrating relationships:

$$
r_{L T}=1.667+0.732 r_{S T}+0.339 \pi \quad \ldots \quad \ldots
$$

From equation (2), the results show that there is a significant positive long-run relationship among short-term interest rates, the rate of inflation, and long-term interest rates. It suggests that an increase in short-term interest rates or the rate of inflation impacts positively on long-term interest rates.

\footnotetext{
${ }^{5}$ The skewness test statistics are of the null hypotheses that the disturbance term in all equations jointly have zero skewness, which is the skewness of a normally distributed variable.

${ }^{6}$ If all of the calculated eigenvalues are less than one (in modulus, if they have imaginary parts), then the model is stable.
} 
The results in table 5 present the short-run speed of adjustment coefficients (the error correction terms) for the set of variables used in our baseline model (model 2) along with the short-run dynamics. The results in table 5 show that all variables in model 2 are significantly positively influenced by their own lagged first differences. The significance of the rate of inflation $\left(-0.224^{*}\right)$ in the long-term interest rates equation indicates that there is a unidirectional short-run causal effect running from the rate of inflation to the long-term interest rates.

The error correction terms presented in the last column of table 4 tell how deviations from the equilibrium are adjusted. ${ }^{7}$ The error correction term of the long-term interest rates equation has an estimated coefficient of -0.126 , which is significant at the $1 \%$ level, implying that about $12.6 \%$ of the disequilibrium is corrected within one quarter. The error correction terms for the other two equations are not significant. Thus, the cointegration relationship only enters significantly in the long-term interest rates equation. Or one can say that the long-term interest rates bear the error correction burden.

\footnotetext{
${ }^{7}$ The significance of the lagged error correction term(s) will indicate the long-term causal relationship. The lagged error correction term contains the long-run information, since it is derived from the long-term cointegration relationship(s).
} 
Table 5: Temporal Causality Results Based on VEC Model 2

\begin{tabular}{|c|c|c|c|c|c|}
\hline \multicolumn{6}{|c|}{ Table 5} \\
\hline \multicolumn{6}{|c|}{ Temporal causality results based on VEC Model 2} \\
\hline & $\Delta($ CMY10YR_Q)(-1) & $\Delta$ (TB3M_Q)(-1) & $\Delta($ CPCE_YOY_Q)(-1) & Constant & ECT \\
\hline \multicolumn{6}{|c|}{ Short-run relationship } \\
\hline \multirow[t]{2}{*}{$\Delta C M Y 10 Y R \_Q$} & $0.221 * *$ & -0.002 & $-0.224^{*}$ & -0.002 & $-0.126 * * *$ \\
\hline & {$[0.08]$} & {$[0.06]$} & {$[0.1]$} & {$[0.03]$} & {$[0.03]$} \\
\hline \multirow[t]{2}{*}{$\Delta$ TB3M_Q } & 0.058 & $0.206 *$ & 0.042 & -0.01 & 0.026 \\
\hline & {$[0.13]$} & {$[0.015]$} & {$[0.15]$} & {$[0.05]$} & {$[0.05]$} \\
\hline \multirow[t]{2}{*}{$\triangle$ CPCE_YOY_Q } & -0.086 & 0.061 & $0.575^{* * *}$ & 0 & -0.011 \\
\hline & {$[0.05]$} & {$[0.03]$} & {$[0.06]$} & {$[0.02]$} & {$[0.02]$} \\
\hline
\end{tabular}

Notes: $1 .{ }^{* *}$ significant at $1 \%$ level, $* *$ significant at $5 \%$ level, $*$ significant at $10 \%$ level; 2 . ECT is an error correction term in the respective difference equation

\subsection{Impulse Response Analysis}

To obtain further insights into the relationship between short-term interest rates and all other variables, an impulse response function (IRF) analysis based on the VEC model from the previous section is conducted in this section. The IRF analysis shows the causality among the variables in a dynamic framework, and outside the period under consideration.

Figure 15 shows how an unexpected change in one variable at the beginning affects the other two variables in model 2 through time. First of all, it can be seen that short-term interest rate shocks cause persistent reactions in both long-term interest rates and the rate of inflation, where the signs are consistent with the estimated long-run trade-off. ${ }^{8}$ In contrast, the initial response of short-term interest rates to a unit shock in long-term interest rates is positive and significant one quarter after the shock and then becomes negative and dies out. Similarly, a long-term interest rate shock directly generates a negative reaction on the rate of inflation one quarter after the shock and dies out. The IRF analysis indicates that an unexpected shock to short-term interest rates has a permanent effect on both long-term interest rates and the rate of inflation but that an unexpected shock to long-term interest rates has a transitory effect.

Overall, the VEC model specification exhibits a significant error correction coefficient for longterm interest rates, with the expected minus sign $\left(-0.126^{* * *}\right)$. This is sufficient for rejecting any

\footnotetext{
${ }^{8}$ Whereas IRF from a stationary VAR die out over time, IRF from a cointegrating VEC model do not always die out.
} 
"no cointegration" hypothesis and confirming the presence of a stable long-run relationship among long-term interest rates, short-term interest rates, and the rate of inflation. The value of this coefficient - that is, the speed of return to equilibrium long-term interest rates - appears to be relatively moderate. In contrast, the estimated error correction coefficients in short-term interest rates and the rate of inflation equations do not contribute to the error correction of a shock.

Figure 15: Impulse Response-VEC Model 2

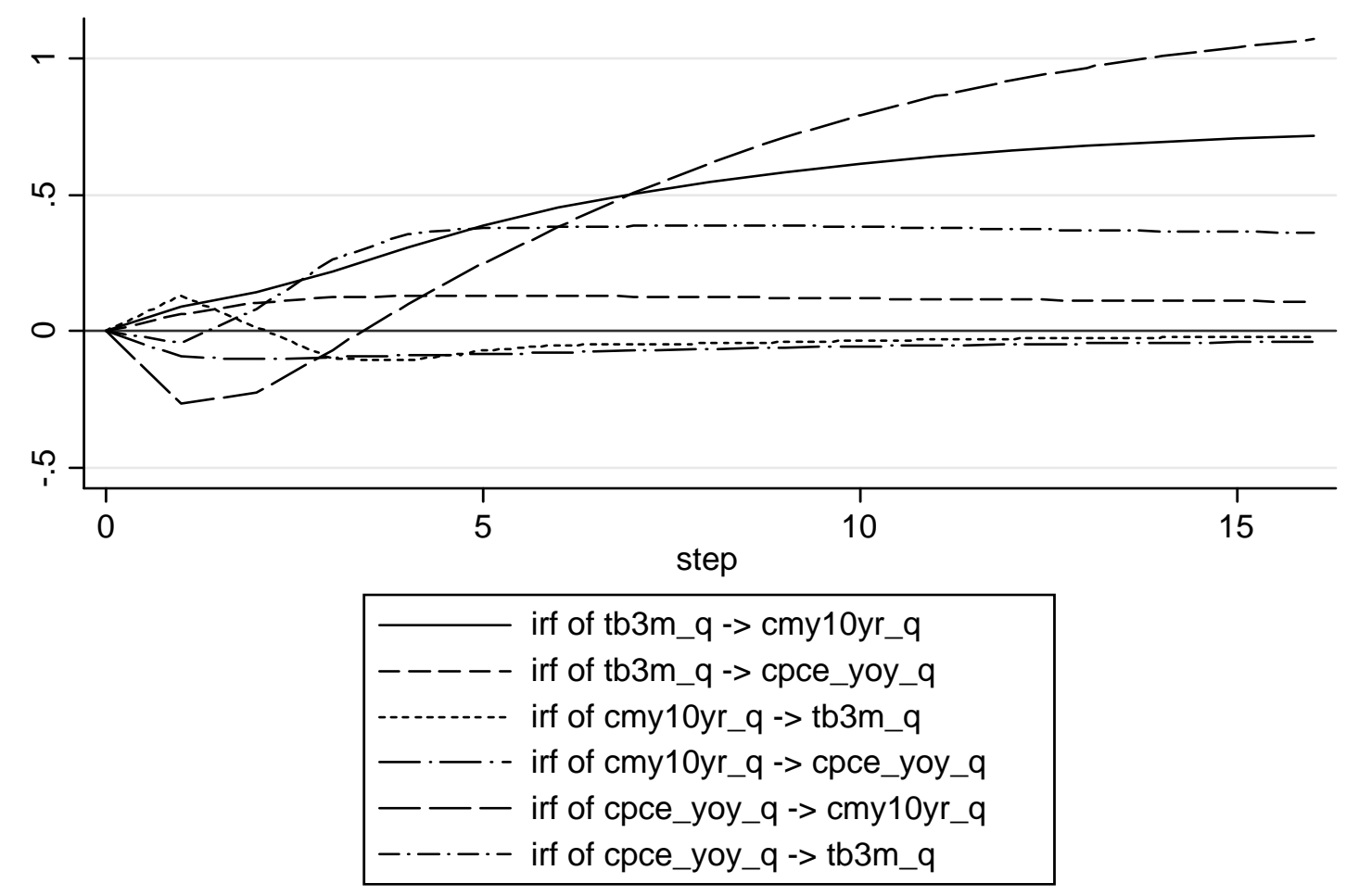




\section{SECTION VII: CONCLUSION}

The empirical findings of this paper support Keynes's view that short-term interest rates are the most important determinants of long-term interest rates in the US. Long-term interest rates on US Treasury securities are positively associated with short-term interest rates on US Treasury bills, after controlling for various relevant economic variables, such as the rates of inflation, the growth rates of economic activity, and government finance variables. The Federal Reserve affects the short-term interest rates through its policy rates and through various other tools of monetary policy. Public finance variables, such as fiscal deficits as a share of nominal GDP or government debt as a ratio of nominal GDP, appear to not exert any upward pressures on the nominal yields of US Treasury securities, contrary to the conventional wisdom.

In future research, it would be useful to situate the empirical findings of this paper in the context of the institutions of modern tax-driven fiat money or "chartalist" theory (Wray 2003, 2012), recent developments in macroeconomic theory (Sims 2013; Woodford 2001), the central bank's operational framework (Bindseil 2004; Fullwiler 2008), and the literature on the coordination between the Treasury (Ministry of Finance) and the central bank in advanced economies with monetary sovereignty. 


\section{REFERENCES}

Akram, T. 2014. “The Economics of Japan's Stagnation.” Business Economics 49(3): 156-75.

Akram, T., and A. Das. 2014a. "Understanding the Low Yields of the Long-Term Japanese Sovereign Debt." Journal of Economic Issues 48(2): 331-40.

Akram, T., and A. Das. 2014b. "The Determinants of Long-Term Japanese Government Bonds' Low Nominal Yields.” Levy Economics Institute Working Paper, No. 818, October.

Akram, T., and A. Das. 2015. "Does Keynesian Theory Explain Indian Government Bond Yields?” Levy Economics Institute Working Paper, No. 834, March.

Baldacci, E., and M. Kumar. 2010. "Fiscal Deficits, Public Debt, and Sovereign Bond Yields." IMF Working Paper, No. 10/184.

Bindseil, U. 2004. Monetary Policy Implementation: Theory, Past, and Present. Oxford and New York: Oxford University Press.

Dickey, D.A. and W. A. Fuller. 1979. "Distribution of the Estimators for Autoregressive Time Series with a Unit Root." Journal of the American Statistical Association 74(366): 42731.

Dickey, D.A. and W. A. Fuller. 1981. "Likelihood Ratio Statistics for Autoregressive Time Series with a Unit Root." Econometrica 49(4): 1057-72.

Fullwiler, S. 2008. "Modern Central Bank Operations: The General Principles." Available at: http://ssrn.com/abstract=1658232 (accessed February 15, 2016).

Gruber, J.W., and S.B. Kamin. 2012. "Fiscal Positions and Government Bond Yields in OECD Countries." Journal of Money, Credit, and Banking 44(8): 1563-87.

Keynes, J.M. 1930. A Treatise on Money, Vol. II: The Applied Theory of Money. London, U.K.: Macmillan

Keynes, J.M. 2007 [1936]. The General Theory of Employment, Interest, and Money. New York, NY: Palgrave Macmillan.

Kregel, J. 2011. "Was Keynes's Monetary Policy À Outrance in the Treatise, A Forerunner of ZIRP and QE? Did He Change his Mind in the General Theory?" Levy Economics Institute, Policy Note, No. 2011/4.

Johansen, S. 1988. "Statistical Analysis of Cointegration Vectors." Journal of Economic Dynamics and Control 12(2): 231-54. 
Johansen, S. 1991. "Estimation and Hypothesis Testing of Cointegration Vectors in Gaussian Vector Autoregressive Models.” Econometrica 59(6): 1551-80.

Johansen, S. 1995. Likelihood-Based Inference in Cointegrated Vector Autoregressive Models. Oxford, UK: Clarendon Press.

Johansen, S., and K. Juselius. 1990. "Maximum Likelihood Estimation and Inference on Cointegration with Applications to the Demand for Money." Oxford Bulletin of Economics and Statistics 52(2): 169-210.

Lam, R.W., and K. Tokuoka. 2011. "Assessing the Risks to the Japanese Government Bond (JGB) Market.” IMF Working Paper, No. 11/292.

Phillips, P.C.B., and P. Perron. 1988. "Testing for a Unit Root in Time Series Regression." Biometrika 75(2): 335-46.

Poghosyan, T. 2012. "Long-Run and Short-Run Determinants of Sovereign Bond Yields in Advanced Economies.” IMF Working Paper, No. 12/271.

Riefler, W.W. 1930. Money Rates and Money Markets in the United States. New York and London: Harper \& Brothers.

Sims, C. 2013. “Paper Money.” American Economic Review 103(2): 563-84.

Tcherneva, P.R. 2011. "Bernanke's Paradox: Can He Reconcile His Position on the Federal Budget with His Recent Charge to Prevent Deflation?" Journal of Post Keynesian Economics 33(3): 411-34.

Tokuoka, K. 2012. “Intergenerational Implications of Fiscal Consolidation in Japan.” IMF Working Paper, No. 12/197.

Thomson Reuters EcoWin. various years. Thomson Reuters EcoWin, subscription service (accessed December 31, 2014).

Tymoigne, E. 2013. "Public Debt and Monetary Sovereignty in the U.S.: Myths and Realities." presented at the Allied Social Science Associations' annual meeting, January 4-6, San Diego, CA.

Woodford, M. 2001. "Fiscal Requirements for Price Stability." Journal of Money, Credit and Banking 33(3): (August) 669-728.

Wray, L.R. 2003. Understanding Modern Money: The Key to Full Employment and Price Stability. Cheltenham, UK; Northampton, MA: Edward Elgar.

Wray, L.R. 2012. Modern Money Theory: A Primer on Macroeconomics for Sovereign Monetary Systems. New York, NY: Palgrave Macmillan. 


\section{APPENDIX TABLES}

Table A1: Unit-root Tests (Level)

\begin{tabular}{|c|c|c|c|c|c|}
\hline \multicolumn{6}{|c|}{ Appendix Table A1 } \\
\hline \multicolumn{6}{|c|}{ Unit-root tests (Level) } \\
\hline Variable & & Tests & Statistic & P-value & Obs. \\
\hline \multirow[t]{6}{*}{ TB6M_Q } & \multirow[t]{2}{*}{ Trend } & ADF & -1.898 & 0.656 & 218 \\
\hline & & PP & -2.189 & 0.496 & 218 \\
\hline & \multirow[t]{2}{*}{ No trend } & ADF & -1.343 & 0.609 & 218 \\
\hline & & PP & -1.679 & 0.442 & 218 \\
\hline & \multirow{2}{*}{$\begin{array}{l}\text { No trend } \\
\text { no constant }\end{array}$} & ADF & -1.035 & 0.617 & 218 \\
\hline & & PP & -1.151 & 0.343 & 218 \\
\hline \multirow[t]{6}{*}{ UST2YR_Q } & \multirow[t]{2}{*}{ Trend } & ADF & -2.911 & 0.159 & 153 \\
\hline & & PP & -3.221 & 0.080 & 153 \\
\hline & \multirow[t]{2}{*}{ No trend } & ADF & -0.806 & 0.817 & 153 \\
\hline & & PP & -1.076 & 0.724 & 153 \\
\hline & \multirow{2}{*}{$\begin{array}{l}\text { No trend } \\
\text { no constant }\end{array}$} & ADF & -1.051 & 0.412 & 153 \\
\hline & & PP & -1.102 & 0.672 & 153 \\
\hline \multirow[t]{6}{*}{ UST5YR_Q } & \multirow[t]{2}{*}{ Trend } & ADF & -1.884 & 0.663 & 210 \\
\hline & & PP & -2.063 & 0.567 & 210 \\
\hline & \multirow[t]{2}{*}{ No trend } & ADF & -1.090 & 0.719 & 210 \\
\hline & & PP & -1.363 & 0.600 & 210 \\
\hline & \multirow{2}{*}{$\begin{array}{l}\text { No trend } \\
\text { no constant }\end{array}$} & ADF & -0.707 & 0.543 & 210 \\
\hline & & PP & -0.787 & 0.562 & 210 \\
\hline \multirow[t]{6}{*}{ UST10YR_Q } & \multirow[t]{2}{*}{ Trend } & ADF & -1.728 & 0.738 & 150 \\
\hline & & PP & -1.920 & 0.644 & 150 \\
\hline & \multirow[t]{2}{*}{ No trend } & ADF & -1.025 & 0.744 & 150 \\
\hline & & PP & -1.328 & 0.617 & 150 \\
\hline & \multirow{2}{*}{$\begin{array}{l}\text { No trend } \\
\text { no constant }\end{array}$} & ADF & -0.598 & 0.542 & 150 \\
\hline & & PP & -0.678 & 0.522 & 150 \\
\hline \multirow[t]{6}{*}{ UST30YR_Q } & \multirow[t]{2}{*}{ Trend } & ADF & -0.814 & 0.815 & 153 \\
\hline & & PP & -3.482 & 0.041 & 153 \\
\hline & \multirow[t]{2}{*}{ No trend } & ADF & -0.608 & 0.869 & 153 \\
\hline & & PP & -0.920 & 0.781 & 153 \\
\hline & \multirow{2}{*}{$\begin{array}{l}\text { No trend } \\
\text { no constant }\end{array}$} & ADF & -0.943 & 0.652 & 153 \\
\hline & & $\mathrm{PP}$ & -0.926 & 0.662 & 153 \\
\hline \multirow[t]{5}{*}{ CMY2YR_Q } & \multirow[t]{2}{*}{ Trend } & ADF & -2.923 & 0.155 & 153 \\
\hline & & PP & -3.226 & 0.079 & 153 \\
\hline & \multirow[t]{2}{*}{ No trend } & ADF & -0.814 & 0.815 & 153 \\
\hline & & $\mathrm{PP}$ & -1.077 & 0.724 & 153 \\
\hline & No trend & ADF & -1.051 & 0.652 & 153 \\
\hline
\end{tabular}




\begin{tabular}{|c|c|c|c|c|c|}
\hline \multicolumn{6}{|c|}{ Appendix Table A1 } \\
\hline \multicolumn{6}{|c|}{ Unit-root tests (Level) } \\
\hline \multirow[t]{2}{*}{ Variable } & & Tests & Statistic & P-value & Obs \\
\hline & no constant & PP & -1.100 & 0.232 & 153 \\
\hline \multirow[t]{6}{*}{ CMY5YR_Q } & \multirow[t]{2}{*}{ Trend } & ADF & -1.586 & 0.798 & 218 \\
\hline & & $\mathrm{PP}$ & -1.799 & 0.705 & 218 \\
\hline & \multirow[t]{2}{*}{ No trend } & ADF & -1.057 & 0.732 & 218 \\
\hline & & PP & -1.336 & 0.612 & 218 \\
\hline & \multirow{2}{*}{$\begin{array}{l}\text { No trend } \\
\text { no constant }\end{array}$} & ADF & -0.778 & 0.656 & 218 \\
\hline & & PP & -0.850 & 0.324 & 218 \\
\hline \multirow[t]{6}{*}{ CMY30YR_Q } & \multirow[t]{2}{*}{ Trend } & ADF & -3.187 & 0.087 & 150 \\
\hline & & PP & -3.488 & 0.041 & 150 \\
\hline & \multirow[t]{2}{*}{ No trend } & ADF & -0.613 & 0.868 & 150 \\
\hline & & PP & -0.919 & 0.782 & 150 \\
\hline & \multirow{2}{*}{$\begin{array}{l}\text { No trend } \\
\text { no constant }\end{array}$} & ADF & -0.941 & 0.682 & 150 \\
\hline & & PP & -0.925 & 0.662 & 150 \\
\hline \multirow[t]{6}{*}{ PCE_YOY_Q } & \multirow[t]{2}{*}{ Trend } & ADF & -1.948 & 0.630 & 219 \\
\hline & & PP & -2.567 & 0.295 & 219 \\
\hline & \multirow[t]{2}{*}{ No trend } & ADF & -1.576 & 0.496 & 219 \\
\hline & & PP & -2.256 & 0.187 & 219 \\
\hline & \multirow{2}{*}{$\begin{array}{l}\text { No trend } \\
\text { no constant }\end{array}$} & ADF & -0.959 & 0.452 & 219 \\
\hline & & PP & -1.337 & 0.212 & 219 \\
\hline \multirow[t]{6}{*}{ CPI_YOY_Q } & \multirow[t]{2}{*}{ Trend } & ADF & -2.183 & 0.500 & 219 \\
\hline & & $\mathrm{PP}$ & -2.782 & 0.204 & 219 \\
\hline & \multirow[t]{2}{*}{ No trend } & ADF & -1.897 & 0.333 & 219 \\
\hline & & $\mathrm{PP}$ & -2.541 & 0.106 & 219 \\
\hline & \multirow{2}{*}{$\begin{array}{l}\text { No trend } \\
\text { no constant }\end{array}$} & ADF & -1.101 & 0.554 & 219 \\
\hline & & $\mathrm{PP}$ & -1.473 & 0.254 & 219 \\
\hline \multirow[t]{6}{*}{ CCPI_YOY_Q } & \multirow[t]{2}{*}{ Trend } & ADF & -1.810 & 0.700 & 219 \\
\hline & & PP & -2.460 & 0.348 & 219 \\
\hline & \multirow[t]{2}{*}{ No trend } & ADF & -1.436 & 0.565 & 219 \\
\hline & & $\mathrm{PP}$ & -2.160 & 0.221 & 219 \\
\hline & \multirow{2}{*}{$\begin{array}{l}\text { No trend } \\
\text { no constant }\end{array}$} & ADF & -0.884 & 0.534 & 219 \\
\hline & & PP & -1.262 & 0.254 & 219 \\
\hline \multirow[t]{6}{*}{ RGDP_YOY_Q } & \multirow[t]{2}{*}{ Trend } & ADF & -3.991 & 0.009 & 218 \\
\hline & & PP & -2.165 & 0.510 & 218 \\
\hline & \multirow[t]{2}{*}{ No trend } & ADF & -3.834 & 0.003 & 218 \\
\hline & & PP & -1.746 & 0.408 & 218 \\
\hline & No trend & ADF & -2.372 & 0.001 & 218 \\
\hline & no constant & PP & -1.049 & 0.436 & 218 \\
\hline BALANCE_Q & Trend & ADF & -1.372 & 0.869 & 215 \\
\hline
\end{tabular}




\begin{tabular}{|c|c|c|c|c|c|}
\hline \multicolumn{6}{|c|}{ Appendix Table A1 } \\
\hline \multicolumn{6}{|c|}{ Unit-root tests (Level) } \\
\hline \multirow[t]{6}{*}{ Variable } & & Tests & Statistic & P-value & Obs. \\
\hline & & $\mathrm{PP}$ & -0.630 & 0.977 & 215 \\
\hline & \multirow[t]{2}{*}{ No trend } & ADF & -1.134 & 0.701 & 215 \\
\hline & & PP & 0.808 & 0.992 & 215 \\
\hline & \multirow{2}{*}{$\begin{array}{l}\text { No trend } \\
\text { no constant }\end{array}$} & ADF & -0.475 & 0.664 & 215 \\
\hline & & PP & 1.231 & 0.341 & 215 \\
\hline \multirow[t]{6}{*}{ PDEBT_Q } & \multirow[t]{2}{*}{ Trend } & ADF & -0.425 & 0.986 & 194 \\
\hline & & PP & -0.962 & 0.949 & 194 \\
\hline & \multirow[t]{2}{*}{ No trend } & ADF & 3.892 & 1.000 & 194 \\
\hline & & PP & 2.118 & 0.992 & 194 \\
\hline & \multirow{2}{*}{$\begin{array}{l}\text { No trend } \\
\text { no constant }\end{array}$} & ADF & 5.525 & 0.934 & 194 \\
\hline & & PP & 3.306 & 0.834 & 194 \\
\hline \multirow[t]{6}{*}{ G_DEBT_Q } & \multirow{2}{*}{ Trend } & ADF & 0.127 & 0.995 & 218 \\
\hline & & PP & -0.522 & 0.983 & 218 \\
\hline & \multirow[t]{2}{*}{ No trend } & ADF & 2.843 & 1.000 & 218 \\
\hline & & PP & 1.367 & 0.997 & 218 \\
\hline & \multirow{2}{*}{$\begin{array}{l}\text { No trend } \\
\text { no constant }\end{array}$} & ADF & 2.815 & 0.994 & 218 \\
\hline & & $\mathrm{PP}$ & 1.688 & 0.534 & 218 \\
\hline \multirow[t]{6}{*}{ DEBT_Q } & \multirow[t]{2}{*}{ Trend } & ADF & -0.714 & 0.972 & 218 \\
\hline & & $\mathrm{PP}$ & -1.000 & 0.944 & 218 \\
\hline & \multirow[t]{2}{*}{ No trend } & ADF & 4.529 & 1.000 & 218 \\
\hline & & PP & 2.312 & 0.999 & 218 \\
\hline & \multirow{2}{*}{$\begin{array}{l}\text { No trend } \\
\text { no constant }\end{array}$} & ADF & 4.129 & 0.992 & 218 \\
\hline & & $\mathrm{PP}$ & 2.636 & 0.341 & 218 \\
\hline \multirow[t]{6}{*}{ BORROW_Q } & \multirow[t]{2}{*}{ Trend } & ADF & -2.264 & 0.454 & 218 \\
\hline & & PP & -2.915 & 0.157 & 218 \\
\hline & \multirow[t]{2}{*}{ No trend } & ADF & -2.256 & 0.187 & 218 \\
\hline & & PP & -2.827 & 0.055 & 218 \\
\hline & \multirow{2}{*}{$\begin{array}{l}\text { No trend } \\
\text { no constant }\end{array}$} & ADF & -0.778 & 0.993 & 218 \\
\hline & & $\mathrm{PP}$ & -1.121 & 0.341 & 218 \\
\hline
\end{tabular}


Table A2: Unit-root Tests (First-difference)

\begin{tabular}{|c|c|c|c|c|c|}
\hline \multicolumn{6}{|c|}{ Appendix Table A2 } \\
\hline \multicolumn{6}{|c|}{ Unit-root tests (First-difference) } \\
\hline Variable & & Tests & Statistic & P-value & Obs. \\
\hline \multirow[t]{6}{*}{$\Delta$ (TB6M_Q) } & \multirow[t]{2}{*}{ Trend } & ADF & -11.907 & 0 & 217 \\
\hline & & PP & -11.819 & 0 & 217 \\
\hline & \multirow[t]{2}{*}{ No trend } & ADF & -11.876 & 0 & 217 \\
\hline & & PP & -11.798 & 0 & 217 \\
\hline & \multirow{2}{*}{$\begin{array}{l}\text { No trend } \\
\text { no constant }\end{array}$} & ADF & -11.900 & 0 & 217 \\
\hline & & PP & -11.824 & 0 & 217 \\
\hline \multirow[t]{6}{*}{$\Delta$ (UST2YR_Q) } & \multirow[t]{2}{*}{ Trend } & ADF & -9.967 & 0 & 152 \\
\hline & & PP & -9.934 & 0 & 152 \\
\hline & \multirow[t]{2}{*}{ No trend } & ADF & -9.958 & 0 & 152 \\
\hline & & PP & -9.934 & 0 & 152 \\
\hline & \multirow{2}{*}{$\begin{array}{l}\text { No trend } \\
\text { no constant }\end{array}$} & ADF & -9.967 & 0 & 152 \\
\hline & & PP & -9.946 & 0 & 152 \\
\hline \multirow[t]{6}{*}{$\Delta($ UST5YR_Q) } & \multirow[t]{2}{*}{ Trend } & ADF & -11.619 & 0 & 209 \\
\hline & & PP & -11.552 & 0 & 209 \\
\hline & \multirow[t]{2}{*}{ No trend } & ADF & -11.545 & 0 & 209 \\
\hline & & PP & -11.495 & 0 & 209 \\
\hline & \multirow{2}{*}{$\begin{array}{l}\text { No trend } \\
\text { no constant }\end{array}$} & ADF & -11.571 & 0 & 209 \\
\hline & & PP & -11.522 & 0 & 209 \\
\hline \multirow[t]{6}{*}{$\Delta$ (UST10YR_Q) } & \multirow[t]{2}{*}{ Trend } & ADF & -11.391 & 0 & 149 \\
\hline & & PP & -11.364 & 0 & 149 \\
\hline & \multirow[t]{2}{*}{ No trend } & ADF & -11.296 & 0 & 149 \\
\hline & & PP & -11.289 & 0 & 149 \\
\hline & \multirow{2}{*}{$\begin{array}{l}\text { No trend } \\
\text { no constant }\end{array}$} & ADF & -11.322 & 0 & 149 \\
\hline & & PP & -11.315 & 0 & 149 \\
\hline \multirow[t]{6}{*}{$\Delta$ (UST30YR_Q) } & \multirow[t]{2}{*}{ Trend } & ADF & -9.180 & 0 & 152 \\
\hline & & PP & -9.152 & 0 & 152 \\
\hline & \multirow[t]{2}{*}{ No trend } & ADF & -9.165 & 0 & 152 \\
\hline & & PP & -9.143 & 0 & 152 \\
\hline & \multirow{2}{*}{$\begin{array}{l}\text { No trend } \\
\text { no constant }\end{array}$} & ADF & -9.167 & 0 & 152 \\
\hline & & PP & -9.150 & 0 & 152 \\
\hline \multirow[t]{6}{*}{$\Delta$ (CMY2YR_Q) } & \multirow[t]{2}{*}{ Trend } & ADF & -10.037 & 0 & 152 \\
\hline & & PP & -10.004 & 0 & 152 \\
\hline & \multirow[t]{2}{*}{ No trend } & ADF & $\begin{array}{l}-10.028 \\
\end{array}$ & 0 & 152 \\
\hline & & PP & -10.005 & 0 & 152 \\
\hline & \multirow{2}{*}{$\begin{array}{l}\text { No trend } \\
\text { no constant }\end{array}$} & ADF & -10.037 & 0 & 152 \\
\hline & & $\mathrm{PP}$ & -10.017 & 0 & 152 \\
\hline$\Delta$ (CMY5YR_Q) & Trend & ADF & -11.848 & 0 & 217 \\
\hline
\end{tabular}




\begin{tabular}{|c|c|c|c|c|c|}
\hline \multicolumn{6}{|c|}{ Appendix Table A2 } \\
\hline \multicolumn{6}{|c|}{ Unit-root tests (First-difference) } \\
\hline \multirow[t]{6}{*}{ Variable } & & Tests & Statistic & P-value & Obs. \\
\hline & & PP & -11.776 & 0 & 217 \\
\hline & \multirow[t]{2}{*}{ No trend } & ADF & -11.799 & 0 & 217 \\
\hline & & PP & -11.742 & 0 & 217 \\
\hline & \multirow{2}{*}{$\begin{array}{l}\text { No trend } \\
\text { no constant }\end{array}$} & ADF & -11.822 & 0 & 217 \\
\hline & & PP & -11.766 & 0 & 217 \\
\hline \multirow[t]{6}{*}{$\Delta$ (CMY30YR_Q) } & \multirow[t]{2}{*}{ Trend } & ADF & -9.234 & 0 & 149 \\
\hline & & PP & -9.204 & 0 & 149 \\
\hline & \multirow[t]{2}{*}{ No trend } & ADF & -9.219 & 0 & 149 \\
\hline & & PP & -9.195 & 0 & 149 \\
\hline & \multirow{2}{*}{$\begin{array}{l}\text { No trend } \\
\text { no constant }\end{array}$} & ADF & -9.221 & 0 & 149 \\
\hline & & PP & -9.203 & 0 & 149 \\
\hline \multirow[t]{6}{*}{$\Delta$ (PCE_YOY_Q) } & \multirow[t]{2}{*}{ Trend } & ADF & -8.935 & 0 & 218 \\
\hline & & PP & -8.900 & 0 & 218 \\
\hline & \multirow[t]{2}{*}{ No trend } & ADF & -8.935 & 0 & 218 \\
\hline & & PP & -8.904 & 0 & 218 \\
\hline & \multirow{2}{*}{$\begin{array}{l}\text { No trend } \\
\text { no constant }\end{array}$} & ADF & -8.955 & 0 & 218 \\
\hline & & PP & -8.924 & 0 & 218 \\
\hline \multirow[t]{6}{*}{$\Delta$ (CPI_YOY_Q) } & \multirow[t]{2}{*}{ Trend } & ADF & -10.037 & 0 & 218 \\
\hline & & PP & -10.036 & 0 & 218 \\
\hline & \multirow[t]{2}{*}{ No trend } & ADF & -10.042 & 0 & 218 \\
\hline & & PP & -10.044 & 0 & 218 \\
\hline & \multirow{2}{*}{$\begin{array}{l}\text { No trend } \\
\text { no constant }\end{array}$} & ADF & -10.066 & 0 & 218 \\
\hline & & PP & -10.068 & 0 & 218 \\
\hline \multirow[t]{6}{*}{$\Delta(C C P I$ YOY_Q) } & \multirow[t]{2}{*}{ Trend } & ADF & -8.784 & 0 & 218 \\
\hline & & $\mathrm{PP}$ & -8.813 & 0 & 218 \\
\hline & \multirow[t]{2}{*}{ No trend } & ADF & -8.770 & 0 & 218 \\
\hline & & PP & -8.806 & 0 & 218 \\
\hline & \multirow{2}{*}{$\begin{array}{l}\text { No trend } \\
\text { no constant }\end{array}$} & ADF & -8.790 & 0 & 218 \\
\hline & & PP & -8.825 & 0 & 218 \\
\hline \multirow[t]{6}{*}{$\Delta$ (RGDP_YOY_Q) } & \multirow[t]{2}{*}{ Trend } & ADF & -10.733 & 0 & 217 \\
\hline & & $\mathrm{PP}$ & -7.585 & 0 & 217 \\
\hline & \multirow[t]{2}{*}{ No trend } & ADF & -10.759 & 0 & 217 \\
\hline & & PP & -7.565 & 0 & 217 \\
\hline & \multirow{2}{*}{$\begin{array}{l}\text { No trend } \\
\text { no constant }\end{array}$} & ADF & -10.785 & 0 & 217 \\
\hline & & PP & -7.581 & 0 & 217 \\
\hline \multirow[t]{3}{*}{$\Delta$ (BALANCE_Q) } & Trend & ADF & -5.419 & 0 & 214 \\
\hline & & PP & -0.630 & 0 & 214 \\
\hline & No trend & ADF & -5.446 & 0 & 214 \\
\hline
\end{tabular}




\begin{tabular}{|c|c|c|c|c|c|}
\hline \multicolumn{6}{|c|}{ Appendix Table A2 } \\
\hline \multicolumn{6}{|c|}{ Unit-root tests (First-difference) } \\
\hline \multirow[t]{4}{*}{ Variable } & & Tests & Statistic & P-value & Obs. \\
\hline & & PP & 0.808 & 0 & 214 \\
\hline & \multirow{2}{*}{$\begin{array}{l}\text { No trend } \\
\text { no constant }\end{array}$} & ADF & -5.126 & 0 & 214 \\
\hline & & PP & 1.231 & 0 & 214 \\
\hline \multirow[t]{6}{*}{$\Delta$ (PDEBT_Q) } & \multirow{2}{*}{ Trend } & ADF & -8.550 & 0 & 193 \\
\hline & & PP & -0.630 & 0 & 193 \\
\hline & \multirow[t]{2}{*}{ No trend } & ADF & -8.052 & 0 & 193 \\
\hline & & PP & 0.808 & 0 & 193 \\
\hline & \multirow{2}{*}{$\begin{array}{l}\text { No trend } \\
\text { no constant }\end{array}$} & ADF & -7.556 & 0 & 193 \\
\hline & & PP & 1.231 & 0 & 193 \\
\hline \multirow[t]{6}{*}{$\Delta($ G_DEBT_Q) } & \multirow[t]{2}{*}{ Trend } & ADF & -11.473 & 0 & 217 \\
\hline & & PP & -8.879 & 0 & 217 \\
\hline & \multirow[t]{2}{*}{ No trend } & ADF & -10.723 & 0 & 217 \\
\hline & & PP & -8.908 & 0 & 217 \\
\hline & \multirow{2}{*}{$\begin{array}{l}\text { No trend } \\
\text { no constant }\end{array}$} & ADF & -10.567 & 0 & 217 \\
\hline & & PP & -8.931 & 0 & 217 \\
\hline \multirow[t]{6}{*}{$\Delta$ (DEBT_Q) } & \multirow[t]{2}{*}{ Trend } & ADF & -8.860 & 0 & 217 \\
\hline & & PP & -12.146 & 0 & 217 \\
\hline & \multirow[t]{2}{*}{ No trend } & ADF & -7.858 & 0 & 217 \\
\hline & & PP & -11.424 & 0 & 217 \\
\hline & \multirow{2}{*}{$\begin{array}{l}\text { No trend } \\
\text { no constant }\end{array}$} & ADF & -7.617 & 0 & 217 \\
\hline & & $\mathrm{PP}$ & -11.265 & 0 & 217 \\
\hline \multirow[t]{6}{*}{$\Delta$ (BORROW_Q) } & \multirow[t]{2}{*}{ Trend } & ADF & -12.589 & 0 & 217 \\
\hline & & $\mathrm{PP}$ & -12.432 & 0 & 217 \\
\hline & \multirow[t]{2}{*}{ No trend } & ADF & -12.615 & 0 & 217 \\
\hline & & $\mathrm{PP}$ & -12.671 & 0 & 217 \\
\hline & \multirow{2}{*}{$\begin{array}{l}\text { No trend } \\
\text { no constant }\end{array}$} & ADF & -12.640 & 0 & 217 \\
\hline & & PP & -12.431 & 0 & 217 \\
\hline
\end{tabular}


Table A3: Multivariate Cointegration Tests (with CMY2YR_Q)

\begin{tabular}{|c|c|c|c|c|c|}
\hline \multicolumn{6}{|c|}{ Appendix Table A3 } \\
\hline \multicolumn{6}{|c|}{ Multi-variate Cointegration Tests (with CMY2YR_Q) } \\
\hline \multicolumn{3}{|c|}{ Trace Test } & \multicolumn{3}{|c|}{ Maximum Eigenvalue Test } \\
\hline Null hypo. & Test Statistic & Critical Value & Null hypo. & Test Statistic & Critical Value \\
\hline \multicolumn{6}{|c|}{ (CMY2YR_Q,TB3M_Q) } \\
\hline$r=0$ & $17.0253 *$ & 20.04 & $r=0$ & 16.7185 & 18.63 \\
\hline $\mathrm{r} \# 1$ & 0.3069 & 6.65 & $\mathrm{r} \# 1$ & 0.3069 & 6.65 \\
\hline \multicolumn{6}{|c|}{ (CMY2YR_Q,CPCE_YOY_Q) } \\
\hline$r=0$ & $14.2675^{*}$ & 20.04 & $r=0$ & 10.4402 & 18.63 \\
\hline $\mathrm{r} \# 1$ & 3.8272 & 6.65 & $\mathrm{r \# 1}$ & 3.8272 & 6.65 \\
\hline \multicolumn{6}{|c|}{ (CMY2YR_Q, N_DEBT_Q) } \\
\hline$r=0$ & $4.0607^{*}$ & 20.04 & $r=0$ & 3.7835 & 18.63 \\
\hline $\mathrm{r} \# 1$ & 0.2772 & 6.65 & r\#1 & 0.2772 & 6.65 \\
\hline \multicolumn{6}{|c|}{ (CMY2YR_Q, N_DEBT_Q,CPCE_YOY_Q) } \\
\hline$r=0$ & $27.8953 *$ & 35.65 & $r=0$ & 18.4536 & 25.52 \\
\hline r\#1 & 9.4417 & 20.04 & r\#1 & 7.8939 & 18.63 \\
\hline $\mathrm{r} \# 2$ & 1.5478 & 6.65 & $\mathrm{r} \# 2$ & 1.5478 & 6.65 \\
\hline \multicolumn{6}{|c|}{ (CMY2YR_Q,TB3M_Q,CPCE_YOY_Q) } \\
\hline$r=0$ & 54.6605 & 35.65 & $r=0$ & 40.8654 & 25.52 \\
\hline r\#1 & $13.7951^{*}$ & 20.04 & r\#1 & 9.0886 & 18.63 \\
\hline r\#2 & 4.7065 & 6.65 & $\mathrm{r} \# 2$ & 4.7065 & 6.65 \\
\hline \multicolumn{6}{|c|}{ (CMY2YR_Q,TB3M_Q, N_DEBT_Q) } \\
\hline$r=0$ & 40.8944 & 35.65 & $r=0$ & 33.6454 & 25.52 \\
\hline r\#1 & $7.2490^{*}$ & 20.04 & $\mathrm{r} \# 1$ & 7.0644 & 18.63 \\
\hline r\#2 & 0.1846 & 6.65 & $\mathrm{r} \# 2$ & 0.1846 & 6.65 \\
\hline \multicolumn{6}{|c|}{ (CMY2YR_Q,TB3M_Q, CPCE_YOY_Q, N_DEBT_Q) } \\
\hline$r=0$ & 71.6723 & 54.46 & $r=0$ & 45.1677 & 32.24 \\
\hline r\#1 & $26.5046 *$ & 35.65 & $\mathrm{r} \# 1$ & 16.974 & 25.52 \\
\hline r\#2 & 9.5305 & 20.04 & $r \# 2$ & 8.3886 & 18.63 \\
\hline r\#3 & 1.1419 & 6.65 & $r \# 3$ & 1.1419 & 6.65 \\
\hline
\end{tabular}


Table A4: Multivariate Cointegration Tests (with CMY5YR_Q)

\begin{tabular}{|c|c|c|c|c|c|}
\hline \multicolumn{6}{|c|}{ Appendix Table A4 } \\
\hline \multicolumn{6}{|c|}{ Multi-variate Cointegration Tests (with CMY5YR_Q) } \\
\hline \multicolumn{3}{|c|}{ Trace Test } & \multicolumn{3}{|c|}{ Maximum Eigenvalue Test } \\
\hline Null hypo. & Test Statistic & Critical Value & Null hypo. & Test Statistic & Critical Value \\
\hline \multicolumn{6}{|c|}{ (CMY5YR_Q, TB3M_Q) } \\
\hline$r=0$ & 30.0483 & 20.04 & $r=0$ & 29.259 & 18.63 \\
\hline $\mathrm{r} \# 1$ & $0.7893 *$ & 6.65 & $\mathrm{r} \# 1$ & 0.7893 & 6.65 \\
\hline \multicolumn{6}{|c|}{ (CMY5YR_Q,CPCE_YOY_Q) } \\
\hline$r=0$ & $16.9834 *$ & 20.04 & $r=0$ & 12.1102 & 18.63 \\
\hline $\mathrm{r} \# 1$ & 4.8731 & 6.65 & $\mathrm{r \# 1}$ & 4.8731 & 6.65 \\
\hline \multicolumn{6}{|c|}{ (CMY5YR_Q, N_DEBT_Q) } \\
\hline$r=0$ & $4.5109^{*}$ & 20.04 & $r=0$ & 4.1336 & 18.63 \\
\hline $\mathrm{r} \# 1$ & 0.3773 & 6.65 & r\#1 & 0.3773 & 6.65 \\
\hline \multicolumn{6}{|c|}{ (CMY5YR_Q, N_DEBT_Q,CPCE_YOY_Q) } \\
\hline$r=0$ & $21.6116 *$ & 35.65 & $r=0$ & 11.6857 & 25.52 \\
\hline r\#1 & 9.9258 & 20.04 & r\#1 & 7.1287 & 18.63 \\
\hline $\mathrm{r} \# 2$ & 2.7971 & 6.65 & $\mathrm{r} \# 2$ & 2.7971 & 6.65 \\
\hline \multicolumn{6}{|c|}{ (CMY5YR_Q,TB3M_Q,CPCE_YOY_Q) } \\
\hline$r=0$ & 57.8304 & 35.65 & $r=0$ & 43.0963 & 25.52 \\
\hline r\#1 & $14.7341 *$ & 20.04 & r\#1 & 11.3297 & 18.63 \\
\hline r\#2 & 3.4044 & 6.65 & $\mathrm{r} \# 2$ & 3.4044 & 6.65 \\
\hline \multicolumn{6}{|c|}{ (CMY5YR_Q,TB3M_Q, N_DEBT_Q) } \\
\hline$r=0$ & 61.848 & 35.65 & $r=0$ & 53.1291 & 25.52 \\
\hline r\#1 & $8.7189^{*}$ & 20.04 & $\mathrm{r} \# 1$ & 8.2341 & 18.63 \\
\hline r\#2 & 0.4848 & 6.65 & $\mathrm{r} \# 2$ & 0.4848 & 6.65 \\
\hline \multicolumn{6}{|c|}{ (CMY5YR_Q,TB3M_Q,CPCE_YOY_Q, N_DEBT_Q) } \\
\hline$r=0$ & 71.7056 & 54.46 & $r=0$ & 49.9497 & 32.24 \\
\hline r\#1 & $21.7558 *$ & 35.65 & $\mathrm{r} \# 1$ & 12.6683 & 25.52 \\
\hline r\#2 & 9.0875 & 20.04 & $r \# 2$ & 7.5123 & 18.63 \\
\hline$r \# 3$ & 1.5753 & 6.65 & r\#3 & 1.5753 & 6.65 \\
\hline
\end{tabular}


Table A5: Multivariate Cointegration Tests (with CMY30YR_Q)

\begin{tabular}{|c|c|c|c|c|c|}
\hline \multicolumn{6}{|c|}{ Appendix Table A5 } \\
\hline \multicolumn{6}{|c|}{ Multi-variate Cointegration Tests (with CMY30YR_Q) } \\
\hline \multicolumn{3}{|c|}{ Trace Test } & \multicolumn{3}{|c|}{ Maximum Eigenvalue Test } \\
\hline Null hypo. & Test Statistic & Critical Value & Null hypo. & Test Statistic & Critical Value \\
\hline \multicolumn{6}{|c|}{ (CMY30YR_Q, TB3M_Q) } \\
\hline$r=0$ & 27.1912 & 20.04 & $r=0$ & 26.3499 & 18.63 \\
\hline $\mathrm{r \# 1}$ & $0.8414 *$ & 6.65 & $\mathrm{r \# 1}$ & 0.8414 & 6.65 \\
\hline \multicolumn{6}{|c|}{ (CMY30YR_Q, CPCE_YOY_Q) } \\
\hline$r=0$ & 21.7197 & 20.04 & $r=0$ & 16.2729 & 18.63 \\
\hline $\mathrm{r} \# 1$ & $5.4468 *$ & 6.65 & $\mathrm{r \# 1}$ & 5.4468 & 6.65 \\
\hline \multicolumn{6}{|c|}{ (CMY30YR_Q, N_DEBT_Q) } \\
\hline$r=0$ & $4.7535^{*}$ & 20.04 & $r=0$ & 4.4725 & 18.63 \\
\hline $\mathrm{r \# 1}$ & 0.281 & 6.65 & $\mathrm{r} \# 1$ & 0.281 & 6.65 \\
\hline \multicolumn{6}{|c|}{ (CMY30YR_Q, N_DEBT_Q,CPCE_YOY_Q) } \\
\hline$r=0$ & $24.8691 *$ & 35.65 & $r=0$ & 15.1354 & 25.52 \\
\hline r\#1 & 9.7337 & 20.04 & $\mathrm{r} \# 1$ & 6.6881 & 18.63 \\
\hline r\#2 & 3.0456 & 6.65 & $\mathrm{r} \# 2$ & 3.0456 & 6.65 \\
\hline \multicolumn{6}{|c|}{ (CMY30YR_Q, TB3M_Q,CPCE_YOY_Q) } \\
\hline$r=0$ & 54.7434 & 35.65 & $r=0$ & 37.3605 & 25.52 \\
\hline r\#1 & $17.3830 *$ & 20.04 & r\#1 & 13.4271 & 18.63 \\
\hline r\#2 & 3.9559 & 6.65 & r\#2 & 3.9559 & 6.65 \\
\hline \multicolumn{6}{|c|}{ (CMY30YR_Q,TB3M_Q, N_DEBT_Q) } \\
\hline$r=0$ & 60.8477 & 35.65 & $r=0$ & 51.8328 & 25.52 \\
\hline r\#1 & $9.0148 *$ & 20.04 & r\#1 & 8.5402 & 18.63 \\
\hline r\#2 & 0.4746 & 6.65 & r\#2 & 0.4746 & 6.65 \\
\hline \multicolumn{6}{|c|}{ (CMY30YR_Q, TB3M_Q,CPCE_YOY_Q, N_DEBT_Q) } \\
\hline$r=0$ & 74.2672 & 54.46 & $r=0$ & 50.1238 & 32.24 \\
\hline $\mathrm{r} \# 1$ & $24.1434 *$ & 35.65 & $\mathrm{r} \# 1$ & 14.9672 & 25.52 \\
\hline r\#2 & 9.1761 & 20.04 & $r \# 2$ & 7.3437 & 18.63 \\
\hline r\#3 & 1.8325 & 6.65 & $r \# 3$ & 1.8325 & 6.65 \\
\hline
\end{tabular}


Table A6: Multivariate Cointegration Tests (with UST2YR_Q)

\begin{tabular}{|c|c|c|c|c|c|}
\hline \multicolumn{6}{|c|}{ Appendix Table A6 } \\
\hline \multicolumn{6}{|c|}{ Multi-variate Cointegration Tests (with UST2YR_Q) } \\
\hline \multicolumn{3}{|c|}{ Trace Test } & \multicolumn{3}{|c|}{ Maximum Eigenvalue Test } \\
\hline Null hypo. & Test Statistic & Critical Value & Null hypo. & Test Statistic & Critical Value \\
\hline \multicolumn{6}{|c|}{ (UST2YR_Q, TB3M_Q) } \\
\hline$r=0$ & 20.5458 & 20.04 & $r=0$ & 20.2148 & 18.63 \\
\hline $\mathrm{r} \# 1$ & $0.3309 *$ & 6.65 & $\mathrm{r} \# 1$ & 0.3309 & 6.65 \\
\hline \multicolumn{6}{|c|}{ (UST2YR_Q, CPCE_YOY_Q) } \\
\hline$r=0$ & 28.1745 & 20.04 & $r=0$ & 24.8635 & 18.63 \\
\hline r\#1 & $3.3110 *$ & 6.65 & $\mathrm{r} \# 1$ & 3.311 & 6.65 \\
\hline \multicolumn{6}{|c|}{ (UST2YR_Q, N_DEBT_Q) } \\
\hline$r=0$ & $4.3595 *$ & 20.04 & $r=0$ & 4.2998 & 18.63 \\
\hline $\mathrm{r} \# 1$ & 0.0597 & 6.65 & $\mathrm{r} \# 1$ & 0.0597 & 6.65 \\
\hline \multicolumn{6}{|c|}{ (UST2YR_Q, N_DEBT_Q,CPCE_YOY_Q) } \\
\hline$r=0$ & $33.3267^{*}$ & 35.65 & $r=0$ & 23.8909 & 25.52 \\
\hline r\#1 & 9.4358 & 20.04 & r\#1 & 7.5778 & 18.63 \\
\hline $\mathrm{r} \# 2$ & 1.858 & 6.65 & $\mathrm{r} \# 2$ & 1.858 & 6.65 \\
\hline \multicolumn{6}{|c|}{ (UST2YR_Q,TB3M_Q, CPCE_YOY_Q) } \\
\hline$r=0$ & 47.4112 & 35.65 & $r=0$ & 28.9846 & 25.52 \\
\hline r\#1 & $18.4266^{*}$ & 20.04 & r\#1 & 13.9921 & 18.63 \\
\hline $\mathrm{r} \# 2$ & 4.4345 & 6.65 & $\mathrm{r} \# 2$ & 4.4345 & 6.65 \\
\hline \multicolumn{6}{|c|}{ (UST2YR_Q, TB3M_Q, N_DEBT_Q) } \\
\hline$r=0$ & 41.6023 & 35.65 & $r=0$ & 34.7714 & 25.52 \\
\hline r\#1 & $6.8309 *$ & 20.04 & r\#1 & 6.7788 & 18.63 \\
\hline r\#2 & 0.0521 & 6.65 & $\mathrm{r} \# 2$ & 0.0521 & 6.65 \\
\hline \multicolumn{6}{|c|}{ (UST2YR_Q,TB3M_Q,CPCE_YOY_Q, N_DEBT_Q) } \\
\hline$r=0$ & 68.4534 & 54.46 & $r=0$ & 38.1243 & 32.24 \\
\hline r\#1 & $30.3291 *$ & 35.65 & r\#1 & 21.6539 & 25.52 \\
\hline r\#2 & 8.6752 & 20.04 & r\#2 & 7.9422 & 18.63 \\
\hline r\#3 & 0.7329 & 6.65 & $r \# 3$ & 0.7329 & 6.65 \\
\hline
\end{tabular}


Table A7: Multivariate Cointegration Tests (with UST5YR_Q)

\begin{tabular}{|c|c|c|c|c|c|}
\hline \multicolumn{6}{|c|}{ Appendix Table A7 } \\
\hline \multicolumn{6}{|c|}{ Multi-variate Cointegration Tests (with UST5YR_Q) } \\
\hline \multicolumn{3}{|c|}{ Trace Test } & \multicolumn{3}{|c|}{ Maximum Eigenvalue Test } \\
\hline Null hypo. & Test Statistic & Critical Value & Null hypo. & Test Statistic & Critical Value \\
\hline \multicolumn{6}{|c|}{ (UST5YR_Q, TB3M_Q) } \\
\hline$r=0$ & $17.0407 *$ & 20.04 & $r=0$ & 16.7133 & 18.63 \\
\hline $\mathrm{r} \# 1$ & 0.3274 & 6.65 & $\mathrm{r} \# 1$ & 0.3274 & 6.65 \\
\hline \multicolumn{6}{|c|}{ (UST5YR_Q,CPCE_YOY_Q) } \\
\hline$r=0$ & $14.2569 *$ & 20.04 & $r=0$ & 10.41 & 18.63 \\
\hline $\mathrm{r} \# 1$ & 3.8469 & 6.65 & $\mathrm{r \# 1}$ & 3.8469 & 6.65 \\
\hline \multicolumn{6}{|c|}{ (UST5YR_Q, N_DEBT_Q) } \\
\hline$r=0$ & 4.0808* & 20.04 & $r=0$ & 3.8061 & 18.63 \\
\hline $\mathrm{r} \# 1$ & 0.2746 & 6.65 & r\#1 & 0.2746 & 6.65 \\
\hline \multicolumn{6}{|c|}{ (UST5YR_Q, N_DEBT_Q,CPCE_YOY_Q) } \\
\hline$r=0$ & $27.8700 *$ & 35.65 & $r=0$ & 18.479 & 25.52 \\
\hline r\#1 & 9.3909 & 20.04 & r\#1 & 7.8432 & 18.63 \\
\hline r\#2 & 1.5478 & 6.65 & $\mathrm{r} \# 2$ & 1.5478 & 6.65 \\
\hline \multicolumn{6}{|c|}{ (UST5YR_Q,TB3M_Q,CPCE_YOY_Q) } \\
\hline$r=0$ & 54.8681 & 35.65 & $r=0$ & 41.1066 & 25.52 \\
\hline r\#1 & $13.7615^{*}$ & 20.04 & r\#1 & 9.0525 & 18.63 \\
\hline r\#2 & 4.709 & 6.65 & $\mathrm{r} \# 2$ & 4.709 & 6.65 \\
\hline \multicolumn{6}{|c|}{ (UST5YR_Q,TB3M_Q, N_DEBT_Q) } \\
\hline$r=0$ & 41.0483 & 35.65 & $r=0$ & 33.8055 & 25.52 \\
\hline r\#1 & $7.2429 *$ & 20.04 & $\mathrm{r} \# 1$ & 7.0542 & 18.63 \\
\hline r\#2 & 0.1887 & 6.65 & $\mathrm{r} \# 2$ & 0.1887 & 6.65 \\
\hline \multicolumn{6}{|c|}{ (UST5YR_Q,TB3M_Q,CPCE_YOY_Q, N_DEBT_Q) } \\
\hline$r=0$ & 71.983 & 54.46 & $r=0$ & 45.5694 & 32.24 \\
\hline r\#1 & $26.4135^{*}$ & 35.65 & $\mathrm{r \# 1}$ & 16.979 & 25.52 \\
\hline r\#2 & 9.4346 & 20.04 & $r \# 2$ & 8.292 & 18.63 \\
\hline$r \# 3$ & 1.1425 & 6.65 & r\#3 & 1.1425 & 6.65 \\
\hline
\end{tabular}


Table A8: Multivariate Cointegration Tests (with UST10YR_Q)

\begin{tabular}{|c|c|c|c|c|c|}
\hline \multicolumn{6}{|c|}{ Appendix Table A8 } \\
\hline \multicolumn{6}{|c|}{ Multi-variate Cointegration Tests (with UST10YR_Q) } \\
\hline \multicolumn{3}{|c|}{ Trace Test } & \multicolumn{3}{|c|}{ Maximum Eigenvalue Test } \\
\hline Null hypo. & Test Statistic & Critical Value & Null hypo. & Test Statistic & Critical Value \\
\hline \multicolumn{6}{|c|}{ (UST10YR_Q, TB3M_Q) } \\
\hline$r=0$ & 28.9278 & 20.04 & $r=0$ & 28.1802 & 18.63 \\
\hline $\mathrm{r} \# 1$ & $0.7476 *$ & 6.65 & $\mathrm{r} \# 1$ & 0.7476 & 6.65 \\
\hline \multicolumn{6}{|c|}{ (UST10YR_Q,CPCE_YOY_Q) } \\
\hline$r=0$ & $16.3982 *$ & 20.04 & $r=0$ & 11.7329 & 18.63 \\
\hline r\#1 & 4.6653 & 6.65 & $\mathrm{r} \# 1$ & 4.6653 & 6.65 \\
\hline \multicolumn{6}{|c|}{ (UST10YR_Q, N_DEBT_Q) } \\
\hline$r=0$ & $4.4324 *$ & 20.04 & $r=0$ & 4.1767 & 18.63 \\
\hline $\mathrm{r} \# 1$ & 0.2557 & 6.65 & $\mathrm{r} \# 1$ & 0.2557 & 6.65 \\
\hline \multicolumn{6}{|c|}{ (UST10YR_Q, N_DEBT_Q,CPCE_YOY_Q) } \\
\hline$r=0$ & $21.1037 *$ & 35.65 & $r=0$ & 11.25 & 25.52 \\
\hline r\#1 & 9.8537 & 20.04 & r\#1 & 7.3726 & 18.63 \\
\hline $\mathrm{r} \# 2$ & 2.4811 & 6.65 & $\mathrm{r} \# 2$ & 2.4811 & 6.65 \\
\hline \multicolumn{6}{|c|}{ (UST10YR_Q,TB3M_Q,CPCE_YOY_Q) } \\
\hline$r=0$ & 55.9023 & 35.65 & $r=0$ & 41.3876 & 25.52 \\
\hline r\#1 & $14.5147^{*}$ & 20.04 & r\#1 & 11.1031 & 18.63 \\
\hline r\#2 & 3.4116 & 6.65 & $\mathrm{r} \# 2$ & 3.4116 & 6.65 \\
\hline \multicolumn{6}{|c|}{ (UST10YR_Q,TB3M_Q, N_DEBT_Q) } \\
\hline$r=0$ & 59.75 & 35.65 & $r=0$ & 51.1503 & 25.52 \\
\hline r\#1 & $8.5997^{*}$ & 20.04 & r\#1 & 8.2466 & 18.63 \\
\hline r\#2 & 0.3531 & 6.65 & $\mathrm{r} \# 2$ & 0.3531 & 6.65 \\
\hline \multicolumn{6}{|c|}{ (UST10YR_Q,TB3M_Q,CPCE_YOY_Q, N_DEBT_Q) } \\
\hline$r=0$ & 69.3743 & 54.46 & $r=0$ & 48.1545 & 32.24 \\
\hline $\mathrm{r} \# 1$ & $21.2199 *$ & 35.65 & r\#1 & 12.1825 & 25.52 \\
\hline $\mathrm{r} \# 2$ & 9.0374 & 20.04 & r\#2 & 7.6578 & 18.63 \\
\hline $\mathrm{r \# 3}$ & 1.3796 & 6.65 & $r \# 3$ & 1.3796 & 6.65 \\
\hline
\end{tabular}


Table A9: Multivariate Cointegration Tests (with UST30YR_Q)

\begin{tabular}{|c|c|c|c|c|c|}
\hline \multicolumn{6}{|c|}{ Appendix Table A9 } \\
\hline \multicolumn{6}{|c|}{ Multi-variate Cointegration Tests (with UST30YR_Q) } \\
\hline \multicolumn{3}{|c|}{ Trace Test } & \multicolumn{3}{|c|}{ Maximum Eigenvalue Test } \\
\hline Null hypo. & Test Statistic & Critical Value & Null hypo. & Test Statistic & Critical Value \\
\hline \multicolumn{6}{|c|}{ (UST30YR_Q, TB3M_Q) } \\
\hline$r=0$ & 26.6469 & 20.04 & $r=0$ & 25.8862 & 18.63 \\
\hline $\mathrm{r} \# 1$ & $0.7608 *$ & 6.65 & $\mathrm{r} \# 1$ & 0.7608 & 6.65 \\
\hline \multicolumn{6}{|c|}{ (UST30YR_Q, CPCE_YOY_Q) } \\
\hline$r=0$ & 20.9878 & 20.04 & $r=0$ & 15.8001 & 18.63 \\
\hline $\mathrm{r} \# 1$ & $5.1877 *$ & 6.65 & $\mathrm{r \# 1}$ & 5.1877 & 6.65 \\
\hline \multicolumn{6}{|c|}{ (UST30YR_Q, N_DEBT_Q) } \\
\hline$r=0$ & $4.6660^{*}$ & 20.04 & $r=0$ & 4.4872 & 18.63 \\
\hline $\mathrm{r} \# 1$ & 0.1788 & 6.65 & r\#1 & 0.1788 & 6.65 \\
\hline \multicolumn{6}{|c|}{ (UST30YR_Q, N_DEBT_Q,CPCE_YOY_Q) } \\
\hline$r=0$ & $24.4150 *$ & 35.65 & $r=0$ & 14.6906 & 25.52 \\
\hline r\#1 & 9.7244 & 20.04 & r\#1 & 7.0177 & 18.63 \\
\hline $\mathrm{r} \# 2$ & 2.7066 & 6.65 & $\mathrm{r} \# 2$ & 2.7066 & 6.65 \\
\hline \multicolumn{6}{|c|}{ (UST30YR_Q,TB3M_Q, CPCE_YOY_Q) } \\
\hline$r=0$ & 53.6688 & 35.65 & $r=0$ & 36.4912 & 25.52 \\
\hline r\#1 & $17.1776^{*}$ & 20.04 & r\#1 & 13.2429 & 18.63 \\
\hline r\#2 & 3.9347 & 6.65 & $\mathrm{r} \# 2$ & 3.9347 & 6.65 \\
\hline \multicolumn{6}{|c|}{ (UST30YR_Q,TB3M_Q, N_DEBT_Q) } \\
\hline$r=0$ & 59.1332 & 35.65 & $r=0$ & 50.3216 & 25.52 \\
\hline r\#1 & $8.8116^{*}$ & 20.04 & $\mathrm{r} \# 1$ & 8.5286 & 18.63 \\
\hline r\#2 & 0.2831 & 6.65 & $\mathrm{r} \# 2$ & 0.2831 & 6.65 \\
\hline \multicolumn{6}{|c|}{ (UST30YR_Q,TB3M_Q,CPCE_YOY_Q, N_DEBT_Q) } \\
\hline$r=0$ & 72.3868 & 54.46 & $r=0$ & 48.8095 & 32.24 \\
\hline r\#1 & $23.5773 *$ & 35.65 & $\mathrm{r} \# 1$ & 14.4459 & 25.52 \\
\hline r\#2 & 9.1314 & 20.04 & $r \# 2$ & 7.6378 & 18.63 \\
\hline r\#3 & 1.5457 & 6.65 & $r \# 3$ & 1.5496 & 6.65 \\
\hline
\end{tabular}


Table A10: Johansen VEC Model (with CMY2YR_Q) Appendix Table A10 Johansen VEC Model (with CMY2YR_Q)

\begin{tabular}{|c|c|c|c|c|}
\hline & Model 1 & Model 2 & Model 3 & Model 4 \\
\hline \multicolumn{5}{|c|}{ Long-run relationship } \\
\hline \multirow[t]{2}{*}{ TB3M_Q } & $-1.078^{* * *}$ & $-1.064 * * *$ & $-1.134^{* * *}$ & $-1.421^{* * *}$ \\
\hline & [0.034] & {$[0.056]$} & {$[0.049]$} & [0.09] \\
\hline \multirow[t]{2}{*}{ CPCE_YOY_Q } & & 0.006 & & $0.415^{* *}$ \\
\hline & & [0.09] & & {$[0.114]$} \\
\hline \multirow[t]{2}{*}{ N_DEBT_Q } & & & -0.003 & -0.011 \\
\hline & & & [0.011] & {$[0.013]$} \\
\hline CONSTANT & -0.526 & -0.563 & -0.5 & -0.814 \\
\hline \multicolumn{5}{|c|}{ Error correction terms } \\
\hline \multirow[t]{2}{*}{$\Delta($ CMY2YR_Q)(-1) } & -0.082 & -0.094 & -0.037 & 0.121 \\
\hline & {$[0.09]$} & {$[0.1]$} & [0.09] & {$[0.06]$} \\
\hline \multirow[t]{2}{*}{$\Delta$ (TB3M_Q)(-1) } & 0.175 & 0.175 & $0.213^{*}$ & $0.281^{* * *}$ \\
\hline & {$[0.1]$} & {$[0.1]$} & {$[0.1]$} & {$[0.07]$} \\
\hline \multirow[t]{2}{*}{$\Delta$ (CPCE_YOY_Q)(-1) } & & -0.006 & & 0.021 \\
\hline & & {$[0.03]$} & & {$[0.02]$} \\
\hline \multirow[t]{2}{*}{$\Delta($ N_DEBT_Q)(-1) } & & & $0.422^{*}$ & $0.445^{* *}$ \\
\hline & & & {$[0.19]$} & [0.14] \\
\hline
\end{tabular}


Table A11: Johansen VEC Model (with CMY5YR_Q)

\begin{tabular}{|c|c|c|c|c|}
\hline \multicolumn{5}{|c|}{ Appendix Table A11 } \\
\hline \multicolumn{5}{|c|}{ Johansen VEC Model (with CMY5YR_Q) } \\
\hline & Model 1 & Model 2 & Model 3 & Model 4 \\
\hline \multicolumn{5}{|c|}{ Long-run relationship } \\
\hline \multirow[t]{2}{*}{ TB3M_Q } & $-1.028^{* * *}$ & $-0.894 * * *$ & $-1.101 * * *$ & $-1.118^{* * *}$ \\
\hline & [0.054] & {$[0.056]$} & {$[0.062]$} & {$[0.069]$} \\
\hline \multirow[t]{2}{*}{ CPCE_YOY_Q } & & $-0.18^{* *}$ & & 0.108 \\
\hline & & {$[0.08]$} & & {$[0.082]$} \\
\hline \multirow[t]{2}{*}{ N_DEBT_Q } & & & -0.005 & 0.001 \\
\hline & & & {$[0.014]$} & {$[0.012]$} \\
\hline CONSTANT & -1.075 & -1.09 & -0.193 & -0.775 \\
\hline \multicolumn{5}{|c|}{ Error correction terms } \\
\hline \multirow[t]{2}{*}{$\Delta($ CMY5YR_Q)(-1) } & $-0.091^{*}$ & $-0.154^{* * *}$ & -0.067 & -0.071 \\
\hline & [0.04] & [0.04] & {$[0.04]$} & {$[0.04]$} \\
\hline \multirow[t]{2}{*}{$\Delta($ TB3M_Q)(-1) } & 0.09 & 0.058 & $0.137 * *$ & $0.156^{* *}$ \\
\hline & [0.05] & [0.06] & {$[0.05]$} & [0.05] \\
\hline \multirow[t]{2}{*}{$\Delta($ CPCE_YOY_Q)(-1) } & & -0.021 & & -0.034 \\
\hline & & [0.02] & & {$[0.02]$} \\
\hline \multirow[t]{2}{*}{$\Delta($ N_DEBT_Q)(-1) } & & & $0.375^{* * *}$ & $0.423 * * *$ \\
\hline & & & {$[0.1]$} & {$[0.1]$} \\
\hline
\end{tabular}


Table A12: Johansen VEC Model (with CMY30YR_Q)

Appendix Table A12

Johansen VEC Model (with CMY30YR_Q)

\begin{tabular}{|c|c|c|c|c|}
\hline & Model 1 & Model 2 & Model 3 & Model 4 \\
\hline \multicolumn{5}{|c|}{ Long-run relationship } \\
\hline \multirow[t]{2}{*}{ TB3M_Q } & $-0.836 * * *$ & $-0.384 * * *$ & $-1 * * *$ & $-1.642 * * *$ \\
\hline & {$[0.083]$} & {$[0.127]$} & {$[0.082]$} & {$[0.171]$} \\
\hline \multirow[t]{2}{*}{ CPCE_YOY_Q } & & $-0.688 * * *$ & & $0.921 * * *$ \\
\hline & & {$[0.206]$} & & {$[0.225]$} \\
\hline \multirow[t]{2}{*}{ N_DEBT_Q } & & & -0.021 & $-0.046^{*}$ \\
\hline & & & {$[0.018]$} & {$[0.024]$} \\
\hline CONSTANT & -2.971 & -2.701 & -0.417 & 1.134 \\
\hline \multicolumn{5}{|c|}{ Error correction terms } \\
\hline \multirow[t]{2}{*}{$\Delta($ CMY30YR_Q)(-1) } & $-0.073^{*}$ & $-0.137 * * *$ & -0.059 & 0.011 \\
\hline & {$[0.03]$} & {$[0.03]$} & {$[0.03]$} & {$[0.02]$} \\
\hline \multirow[t]{2}{*}{$\Delta($ TB3M_Q)(-1) } & 0.072 & -0.077 & $0.117^{*}$ & $0.139 * * *$ \\
\hline & {$[0.06]$} & {$[0.06]$} & {$[0.05]$} & {$[0.03]$} \\
\hline \multirow[t]{2}{*}{$\Delta($ CPCE_YOY_Q)(-1) } & & -0.014 & & 0.006 \\
\hline & & {$[0.02]$} & & {$[0.01]$} \\
\hline \multirow[t]{2}{*}{$\Delta(N$ N_DEBT_Q)(-1) } & & & $0.411 * * *$ & $0.299 * * *$ \\
\hline & & & {$[0.1]$} & {$[0.07]$} \\
\hline
\end{tabular}


Table A13: Johansen VEC Model (with UST2YR_Q)

Appendix Table A13

Johansen VEC Model (with UST2YR_Q)

\begin{tabular}{|c|c|c|c|c|}
\hline & Model 1 & Model 2 & Model 3 & Model 4 \\
\hline \multicolumn{5}{|c|}{ Long-run relationship } \\
\hline \multirow[t]{2}{*}{ TB3M_Q } & $-1.08 * * *$ & $-1.064 * * *$ & $-1.137^{* * *}$ & $-1.433^{* * *}$ \\
\hline & {$[0.035]$} & {$[0.056]$} & {$[0.05]$} & {$[0.088]$} \\
\hline \multirow[t]{2}{*}{ CPCE_YOY_Q } & & 0.005 & & $0.426 * * *$ \\
\hline & & [0.09] & & {$[0.115]$} \\
\hline \multirow[t]{2}{*}{ N_DEBT_Q } & & & -0.003 & -0.011 \\
\hline & & & [0.011] & {$[0.013]$} \\
\hline CONSTANT & -0.514 & -0.551 & 0.529 & 0.867 \\
\hline \multicolumn{5}{|c|}{ Error correction terms } \\
\hline \multirow[t]{2}{*}{$\Delta$ (UST2YR_Q)(-1) } & -0.08 & -0.093 & -0.034 & 0.123 \\
\hline & {$[0.09]$} & {$[0.1]$} & {$[0.09]$} & {$[0.06]$} \\
\hline \multirow[t]{2}{*}{$\Delta($ TB3M_Q)(-1) } & 0.176 & 0.175 & $0.214^{*}$ & $0.28 * * *$ \\
\hline & {$[0.1]$} & {$[0.1]$} & {$[0.09]$} & {$[0.07]$} \\
\hline \multirow[t]{2}{*}{$\Delta($ CPCE_YOY_Q)(-1) } & & -0.007 & & 0.021 \\
\hline & & {$[0.03]$} & & {$[0.02]$} \\
\hline \multirow[t]{2}{*}{$\Delta($ N_DEBT_Q)(-1) } & & & $0.423^{*}$ & $0.441^{* *}$ \\
\hline & & & {$[0.19]$} & {$[0.14]$} \\
\hline
\end{tabular}


Table A14: Johansen VEC Model (with UST5YR_Q)

\begin{tabular}{|c|c|c|c|c|}
\hline \multicolumn{5}{|c|}{ Appendix Table A14 } \\
\hline \multicolumn{5}{|c|}{ Johansen VEC Model (with UST5YR_Q) } \\
\hline & Model 1 & Model 2 & Model 3 & Model 4 \\
\hline \multicolumn{5}{|c|}{ Long-run relationship } \\
\hline \multirow[t]{2}{*}{ TB3M_Q } & $-1.027^{* * *}$ & $-0.9 * * *$ & $-1.111^{* * *}$ & $-1.129 * * *$ \\
\hline & {$[0.056]$} & {$[0.066]$} & {$[0.064]$} & [0.071] \\
\hline \multirow[t]{2}{*}{ CPCE_YOY_Q } & & $-0.176 *$ & & 0.113 \\
\hline & & [0.092] & & {$[0.083]$} \\
\hline \multirow[t]{2}{*}{ N_DEBT_Q } & & & -0.005 & 0.001 \\
\hline & & & {$[0.014]$} & {$[0.012]$} \\
\hline CONSTANT & -1.083 & -1.103 & 0.081 & 0.69 \\
\hline \multicolumn{5}{|c|}{ Error correction terms } \\
\hline \multirow[t]{2}{*}{$\Delta$ (UST5YR_Q)(-1) } & $-0.091^{*}$ & $-0.154 * * *$ & -0.063 & -0.066 \\
\hline & {$[0.04]$} & [0.04] & [0.04] & {$[0.04]$} \\
\hline \multirow[t]{2}{*}{$\Delta($ TB3M_Q)(-1) } & 0.09 & 0.059 & $0.138^{* *}$ & $0.158^{* *}$ \\
\hline & {$[0.05]$} & {$[0.06]$} & {$[0.05]$} & {$[0.05]$} \\
\hline \multirow[t]{2}{*}{$\triangle($ CPCE_YOY_Q)(-1) } & & -0.022 & & -0.033 \\
\hline & & [0.02] & & {$[0.02]$} \\
\hline \multirow[t]{2}{*}{$\Delta($ N_DEBT_Q)(-1) } & & & $0.381^{* * *}$ & $0.427^{* * *}$ \\
\hline & & & {$[0.1]$} & [0.1] \\
\hline
\end{tabular}


Table A15: Johansen VEC Model (with UST30YR_Q)

Appendix Table A15

Johansen VEC Model (with UST30YR_Q)

\begin{tabular}{|c|c|c|c|c|}
\hline & Model 1 & Model 2 & Model 3 & Model 4 \\
\hline \multicolumn{5}{|c|}{ Long-run relationship } \\
\hline \multirow[t]{2}{*}{ TB3M_Q } & $-0.837 * * *$ & $-0.338 * * *$ & $-1.003 * * *$ & $-1.641 * * *$ \\
\hline & {$[0.083]$} & {$[0.126]$} & {$[0.081]$} & {$[0.169]$} \\
\hline \multirow[t]{2}{*}{ CPCE_YOY_Q } & & $-0.681 * * *$ & & $0.915^{* * *}$ \\
\hline & & {$[0.204]$} & & {$[0.223]$} \\
\hline \multirow[t]{2}{*}{ N_DEBT_Q } & & & -0.023 & $-0.047 * * *$ \\
\hline & & & {$[0.018]$} & {$[0.024]$} \\
\hline CONSTANT & -2.962 & -2.69 & -0.312 & 1.201 \\
\hline \multicolumn{5}{|c|}{ Error correction terms } \\
\hline \multirow[t]{2}{*}{$\Delta$ (UST30YR_Q)(-1) } & $-0.073 *$ & $-0.137 * * *$ & -0.058 & 0.011 \\
\hline & {$[0.03]$} & {$[0.03]$} & {$[0.03]$} & {$[0.02]$} \\
\hline \multirow[t]{2}{*}{$\Delta($ TB3M_Q)(-1) } & 0.073 & -0.076 & $0.119^{*}$ & $0.141^{* * *}$ \\
\hline & {$[0.06]$} & {$[0.06]$} & {$[0.05]$} & {$[0.03]$} \\
\hline \multirow[t]{2}{*}{$\Delta$ (CPCE_YOY_Q)(-1) } & & -0.015 & & 0.006 \\
\hline & & {$[0.02]$} & & {$[0.01]$} \\
\hline \multirow[t]{2}{*}{$\Delta\left(N_{1}\right.$ DEBT_Q)(-1) } & & & $0.412 * * *$ & $0.301 * * *$ \\
\hline & & & {$[0.1]$} & {$[0.07]$} \\
\hline
\end{tabular}

